\title{
日射遮蔽物を有する空の日射熱取得簡易計算法 A SIMPLIFIED METHODOLOGY FOR CALCULATING SOLAR HEAT GAIN THROUGH WINDOWS WITH SHADING DEVICES
}

\author{
児島輝 樹*, 二宮秀與** \\ Teruki KOJIMA and Hideyo NIMIYA
}

\begin{abstract}
In the cooling/heating loads simulation for buildings, it is too difficult to estimate the solar heat gain through the windows with shading devices using the detailed and complicated calculation method (e.g. JIS A 2103) and the off-normal optical characteristic parameters in each time. This paper proposed a simplified methodology for calculating hourly or daily accumulated solar heat gain through the windows with shading devices using relation between solar heat gain coefficients of glazing with and without shading devices. In addition, this paper showed the accuracy of proposed models.
\end{abstract}

\section{Keywords : Solar heat gain coefficient, Solar attenuation coefficient, Shading device, Wndow}

日射熱取得率，遮蔽効果係数，日射遮蔽物，空

\section{1.はじめに}

持続可能な低炭素社会の実現に向けて, 2020 年までに新築住宅・ 建築物について段階的に「エネルギーの使用の合理化に関する建築 主等及び特定建築物の所有者の判断の基準」1)（以下，省エネ基準） への適合を義務化する施策が推進されている。住宅の省エネ基準で 外皮の日射熱取得は, 平成 11 年基準 ${ }^{2)}$ まで夏期日射取得係数 $(\mu)$ で, 平成 25 年基準 ${ }^{3)}$, 4) 以降は冷房期の外皮平均日射熱取得率 $\left(\eta_{\mathrm{A}}\right)$ で評価されている。このうち空（開口部）の日射遮蔽の手法として 平成 11 年基準までは,「ひさし等のオーバーハング型の日除け」や 「レースカーテン，和障子，内付ブラインド，外付ブラインド等の 付属部材」が認められたが, 平成 25 年基準以降は, 「ガラスの入射 角特性」を考慮する一方, 日射遮蔽物（付属部材）は省エネ基準の 義務化を意図して建築的手法のみに限定されるようになり「レース カーテン, 内付ブラインド等の付属部材」が対象外となった。しか し, 冷房期に様々な日射遮蔽物を用いて日射を遮ることは, 室内の 熱的快適性を向上し冷房エネルギーを削減するための有効な手法の 一つであり，住まい手にその効果を示し住まい方に工夫を促すこと は非常に重要である。

2014 年 4 月, 空及びドアの日射熱取得率の計算法 JIS A 21035) と試験法 JIS A 1493 ${ }^{6}$ が制定され，従来の JIS R $3106^{7)}$ によるガラ スの日射熱取得率の評価に加えてスクリーンやブラインドなどの日 射遮蔽物やサッシフレームを含む空全体での日射熱取得率を評価す ることができるようになった。これらの評価法では，主に空製品同 士の横並び評価を目的としている。そのため, 空面に対して垂直方 向から日射が入射すること（以下，垂直入射）を前提として日射熱
取得率の評価をしている。したがって，その值を熱負荷計算等に適 用するには, 空面に対して斜め方向から日射が入射すること(以下， 斜め入射）を考慮した何らかの補正が必要となる。そのため，計算 法の附属書には，斜め入射に対する板ガラスの光学特性の計算方法 やプロファイル角特性を考慮したブラインドの光学特性の計算方法 が記載されており，これらを用いて空方位に対寸る太陽位置ごとに 時々刻々の日射熱取得率を計算することはできる。しかし，この計 算法は, 光学特性の多重反射計算と, 面材間の温度と熱抵抗の反復 収束計算をする必要があり, 理論的には可能であるが熱負荷計算で 実行することは現実的ではない。国内の熱負荷計算プログラムに $\mathrm{SMASH}^{8)}, \mathrm{AE}-\mathrm{Sim} / \mathrm{Heat}^{9}{ }^{9}$ や $\mathrm{HASP}^{10)}$ 等があるが，これらのプログ ラムにおける空の日射熱取得の計算では， $3 \mathrm{~mm}$ 透明ガラスの入射 角特性を表す入射角の関数を用いて垂直入射時の日射熱取得を斜め 入射時の日射熱取得に変換している。また，前述の省エネ基準にお いては，ガラスの入射角特性は考慮されているが，ブラインドなど の日射遮蔽物の入射角特性は考慮されていない。

郡ら ${ }^{11}$ は, ブラインドの日除けが無効な成分比を用いてブライン ド内側及び内蔵一般空の入射角，プロファイル角変動に伴う日射熱 取得率，透過率の実用的推定法を提案している。しかし，この手法 では，ブラインドスラット間の相互反射は考慮されていない。

本研究では, 詳細計算法である JIS A 2103 を用いて計算した日射 遮蔽物を有しない空と日射遮蔽物を有寸る空の日射熱取得率の関係 から，時刻別や日積算での空の日射熱取得簡易計算法を提案する。 また, 詳細計算と提案した簡易計算による空の日射熱取得の比較を 行い計算の精度を検証する。

\footnotetext{
* YKK AP (侏)，鹿児島大学大学院理工学研究科博士後期課程 大学院生・修士 (工学)
}

** 鹿児島大学大学院理工学研究科 教授・博士 (工学)
YKK AP Inc., Grad. Stud., Graduate School of Science and Engineering. Kagoshima Univ., M.Eng.

Prof., Graduate School of Science and Engineering, Kagoshima Univ., Dr.Eng. 


\section{2、斜め入射に対するガラスの遮蔽効果を考慮した簡易計算}

詳細計算による空の日射熱取得及び斜め入射に対するガラスの遮 蔽効果を考慮した簡易計算による空の日射熱取得は, それぞれ式 (1) 及び式(2)によって得られる。

$$
\begin{aligned}
& \mathrm{G}_{\mathrm{w}}(\mathrm{t})=\left(\mathrm{I}_{\mathrm{d}}(\mathrm{t}) \times \eta_{\mathrm{d}}(\mathrm{t})+\mathrm{I}_{\mathrm{s}}(\mathrm{t}) \times \eta_{\mathrm{s}}+\mathrm{I}_{\mathrm{g}}(\mathrm{t}) \times \eta_{\mathrm{g}}\right) \times \mathrm{A}_{\mathrm{w}} \\
& \mathrm{G}_{\mathrm{w}}^{\prime}(\mathrm{t})=\left(\mathrm{I}_{\mathrm{d}}(\mathrm{t}) \times \mathrm{f}_{\theta, \mathrm{d}}(\mathrm{t})+\mathrm{I}_{\mathrm{s}}(\mathrm{t}) \times \mathrm{f}_{\theta, \mathrm{s}}+\mathrm{I}_{\mathrm{g}}(\mathrm{t}) \times \mathrm{f}_{\theta, \mathrm{g}}\right) \times \eta_{0} \times \mathrm{A}_{\mathrm{w}}
\end{aligned}
$$

式(1), 式(2) 中の $\eta$ は, 日射遮蔽物を有するまたは有しない空の

Table1 Calculation condition

\section{Calculation: J IS A 2103}

Boundary condition: Summer

Climatic data: EA weather data $1981-2000^{12)}$

Year (8760 hours): Standard year

City (1 location): Tokyo

Orientation (8 directions): S, SW, W, NW, N, NE, E, SE

Ground reflectance: 0.1

Shading type: External or internal venetian blind

Slat angle $(\psi):-75,-45, \pm 0,+45,+75$ degrees

Slat length: $25 \mathrm{~mm}$

Slat reflectance $(\rho): 0.0$ to 1.0 every 0.2

Ratio of specular reflection: 0.0

Glazing type : Clear $3 \mathrm{~mm}+$ air $12 \mathrm{~mm}+$ clear $3 \mathrm{~mm}$

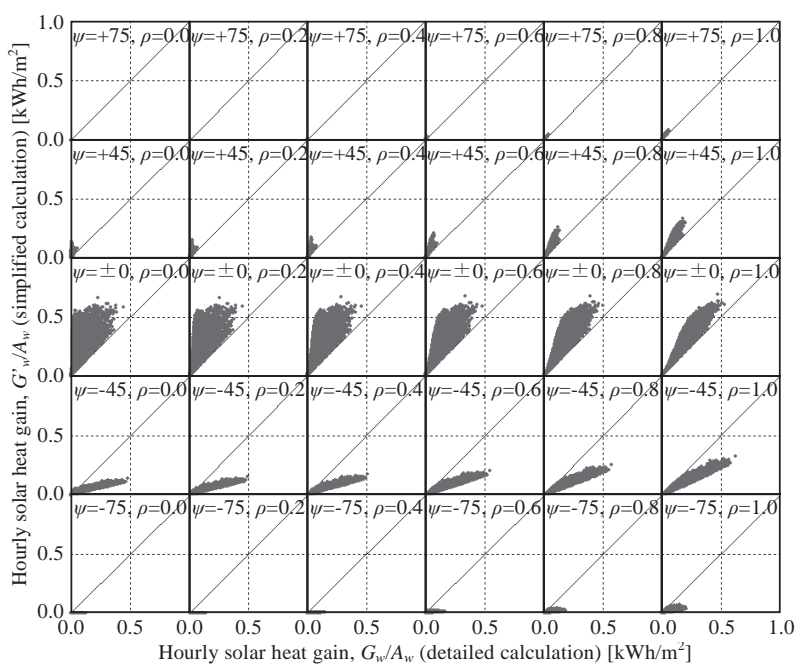

Fig.1 Comparison of hourly solar heat gain

(external venetian blind, simplified calculation by Eq.(2) vs. detailed calculation by Eq.(1))

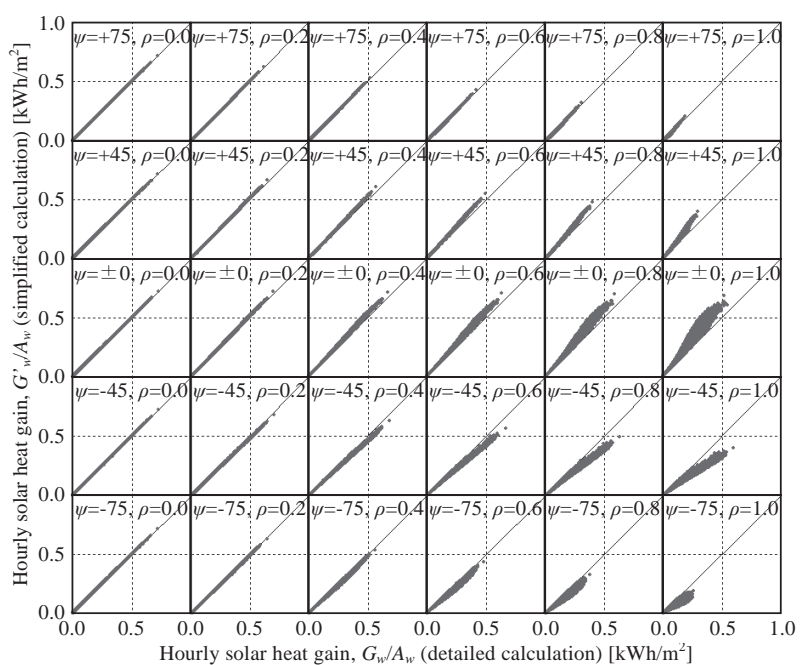

Fig.2 Comparison of hourly solar heat gain

(internal venetian blind, simplified calculation by Eq.(2) vs. detailed calculation by Eq.(1))
日射熱取得率を表し，すべて JIS A 2103 （以下，JISまたは詳細計 算法）に基づいて算出する。式(2)中の $\mathrm{f}_{\theta}$ は，ガラスの斜め入射に対 する遮蔽効果係数を表す。Fig.1，Fig.2 に Table1 に示寸計算条件 における外付ブラインドと内付ブラインドの式(1)の詳細計算での 空の日射熱取得と式 (2)の簡易計算での空の日射熱取得の関係を示 す。図の個々のグラフ中の標本数は， 8 方位 $\times 4386$ 時間（昼間注 1$)$ の合計 35088 である。図より，簡易計算ではブラインドのプロファ イル角注 ${ }^{2)}$ に対する遮蔽効果が考慮されていないためバラつきが大 きく精度よく日射熱取得を計算できていない。したがって，斜め入 射に対するガラスの遮蔽効果だけでなく斜め入射に対する日射遮蔽 物の遮蔽効果も考慮する必要があると考えられる。

\section{3．時刻別の日射熱取得の簡易計算法}

斜め入射に対する日射遮蔽物の時刻別の遮蔽効果係数をモデル化

\begin{tabular}{|c|c|c|}
\hline No. & Shading type & Solar property \\
\hline 1 & External roller shade & $\begin{array}{l}\text { Incident angle }(\mathrm{i}): 0 \text { to }+90 \text { degrees every } 5 \text { degrees } \\
\text { Transmittance }(\tau): 0.0 \text { to } 1.0 \text { every } 0.05 \\
\text { Reflectance }(\rho): 0.0 \text { to } 1.0 \text { every } 0.05 \\
\text { Note } \tau+\rho \leq 1.0\end{array}$ \\
\hline 2 & Internal roller shade & $\begin{array}{l}\text { Incident angle (i): } 0 \text { to }+90 \text { degrees every } 5 \text { degrees } \\
\text { Transmittance }(\tau): 0.0 \text { to } 1.0 \text { every } 0.05 \\
\text { Reflectance }(\rho): 0.0 \text { to } 1.0 \text { every } 0.05 \\
\text { Note } \tau+\rho \leq 1.0\end{array}$ \\
\hline 3 & External venetian blind & $\begin{array}{l}\text { Profile angle }(\phi):-90 \text { to }+90 \text { degrees every } 5 \text { degrees } \\
\text { A zimuth angle }(\gamma):-90 \text { to }+90 \text { degrees every } 5 \text { degrees } \\
\text { Slat angle }(\psi):-75,-45, \pm 0,+45,+75 \text { degrees } \\
\text { Slat length: } 25 \mathrm{~mm} \\
\text { Slat reflectance }(\rho): 0.0 \text { to } 1.0 \text { every } 0.05 \\
\text { Ratio of specular reflection: } 0.0 \text { to } 0.2 \text { every } 0.05\end{array}$ \\
\hline 4 & Internal venetian blind & $\begin{array}{l}\text { Profile angle }(\phi):-90 \text { to }+90 \text { degrees every } 5 \text { degrees } \\
\text { A zimuth angle }(\gamma):-90 \text { to }+90 \text { degrees every } 5 \text { degrees } \\
\text { Slat angle }(\psi):-75,-45, \pm 0,+45,+75 \text { degrees } \\
\text { Slat length: } 25 \mathrm{~mm} \\
\text { Slat reflectance }(\rho): 0.0 \text { to } 1.0 \text { every } 0.05 \\
\text { Ratio of specular reflection: } 0.0 \text { to } 0.2 \text { every } 0.05\end{array}$ \\
\hline
\end{tabular}
するために JIS に基づいて入射角ごとの日射熱取得率を計算する。

Table3 Glazing type and the solar heat gain coefficient

\begin{tabular}{|c|c|c|}
\hline No. & Glazing type (external side to internal side) & $\eta_{\text {non-sh }, 0}$ \\
\hline 1 & Clear $3 \mathrm{~mm}$ & 0.88 \\
\hline 2 & Clear $6 \mathrm{~mm}$ & 0.85 \\
\hline 3 & Heat absorbing $6 \mathrm{~mm}$ & 0.65 \\
\hline 4 & Solar reflective $6 \mathrm{~mm}$ & 0.69 \\
\hline 5 & High solar reflective(SGY 32) $6 \mathrm{~mm}$ & 0.50 \\
\hline 6 & High solar reflective(SS8) $6 \mathrm{~mm}$ & 0.22 \\
\hline 7 & Clear $3 \mathrm{~mm}+$ air $12 \mathrm{~mm}+$ clear $3 \mathrm{~mm}$ & 0.79 \\
\hline 8 & Clear $6 \mathrm{~mm}+$ air $12 \mathrm{~mm}+$ clear $6 \mathrm{~mm}$ & 0.74 \\
\hline 9 & Heat absorbing $6 \mathrm{~mm}+$ air $12 \mathrm{~mm}+$ clear $6 \mathrm{~mm}$ & 0.52 \\
\hline 10 & Solar reflective $6 \mathrm{~mm}+$ air $12 \mathrm{~mm}+$ clear $6 \mathrm{~mm}$ & 0.60 \\
\hline 11 & High solar reflective(SGY 32) $6 \mathrm{~mm}+$ air $12 \mathrm{~mm}+$ clear $6 \mathrm{~mm}$ & 0.39 \\
\hline 12 & High solar reflective(SS8) $6 \mathrm{~mm}+$ air $12 \mathrm{~mm}+$ clear $6 \mathrm{~mm}$ & 0.16 \\
\hline 13 & Low-E(H) $3 \mathrm{~mm}+$ air $12 \mathrm{~mm}+$ clear $3 \mathrm{~mm}$ & 0.67 \\
\hline 14 & Low-E(M) $3 \mathrm{~mm}+$ air $12 \mathrm{~mm}+$ clear $3 \mathrm{~mm}$ & 0.59 \\
\hline 15 & Low-E(L) $3 \mathrm{~mm}+$ air $12 \mathrm{~mm}+$ clear $3 \mathrm{~mm}$ & 0.40 \\
\hline 16 & Clear $3 \mathrm{~mm}+$ air $12 \mathrm{~mm}+$ low-E $(H) 3 \mathrm{~mm}$ & 0.74 \\
\hline 17 & Clear $3 \mathrm{~mm}+$ air $12 \mathrm{~mm}+10 \mathrm{w}-\mathrm{E}$ (M) $3 \mathrm{~mm}$ & 0.64 \\
\hline 18 & Clear $3 \mathrm{~mm}+$ air $12 \mathrm{~mm}+$ low-E (L) 3mm & 0.49 \\
\hline 19 & Clear $3 \mathrm{~mm}+$ air $12 \mathrm{~mm}+$ clear $3 \mathrm{~mm}+$ air $12 \mathrm{~mm}+$ clear $3 \mathrm{~mm}$ & 0.72 \\
\hline 20 & Low-E(H) $3 \mathrm{~mm}+$ air $12 \mathrm{~mm}+$ clear $3 \mathrm{~mm}+$ air $12 \mathrm{~mm}+$ clear $3 \mathrm{~mm}$ & 0.61 \\
\hline 21 & Low-E (M) $3 \mathrm{~mm}+$ air $12 \mathrm{~mm}+$ clear $3 \mathrm{~mm}+$ air $12 \mathrm{~mm}+$ clear $3 \mathrm{~mm}$ & 0.54 \\
\hline 22 & Low-E (L) $3 \mathrm{~mm}+$ air $12 \mathrm{~mm}+$ clear $3 \mathrm{~mm}+$ air $12 \mathrm{~mm}+$ clear $3 \mathrm{~mm}$ & 0.37 \\
\hline 23 & Clear $3 m m+$ air $12 m m+c l e a r 3 m m+$ low-E $(H) 3 m m$ & 0.67 \\
\hline 24 & Clear $3 \mathrm{~mm}+$ air $12 \mathrm{~mm}+\mathrm{clear} 3 \mathrm{~mm}+$ low-E (M) $3 \mathrm{~mm}$ & 0.59 \\
\hline 25 & Clear 3mm + air $12 \mathrm{~mm}+$ clear $3 \mathrm{~mm}+$ low-E(L) 3mm & 0.46 \\
\hline 26 & Low-E(H) $3 \mathrm{~mm}+$ air $12 \mathrm{~mm}+$ clear $3 \mathrm{~mm}+$ air $12 \mathrm{~mm}+$ low $-\mathrm{E}(\mathrm{H}) 3 \mathrm{~mm}$ & 0.57 \\
\hline 27 & Low-E(M) $3 \mathrm{~mm}+$ air $12 \mathrm{~mm}+$ clear $3 \mathrm{~mm}+$ air $12 \mathrm{~mm}+$ low-E (M) $3 \mathrm{~mm}$ & 0.46 \\
\hline 28 & Low-E(L) $3 m m+$ air $12 m m+$ clear $3 m m+$ air $12 m m+$ low-E(L) 3mm & 0.27 \\
\hline \multicolumn{3}{|c|}{  } \\
\hline
\end{tabular}
at normal incidence 


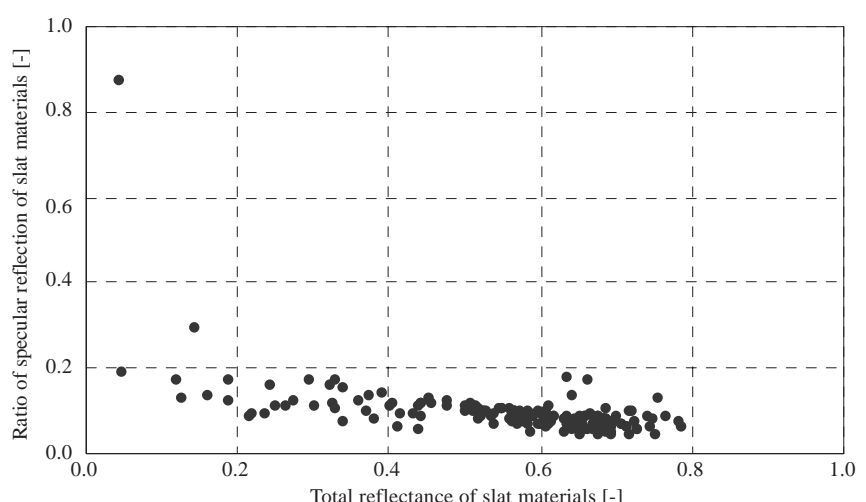

Fig.3 Ratio of specular reflection of slat materials in the market

Table 2 に計算に用いる日射遮蔽物の種類, Table 3 に計算に用いる ガラスの種類と垂直入射時の日射熱取得率を示す。日射遮蔽物やガ ラスの構成は, JIS の附属書を参考に作成した。また, 日射遮蔽の 主目的は冷房負荷削減にあるため境界条件は夏期とした。なお，ブ ラインドスラットの鏡面反射率比 (鏡面反射率／全反射率) は, Fig.3 注 ${ }^{3)}$ に示寸市販されているべネシャンブラインドのスラット材の全 反射率と鏡面反射率比の関係から 0.0 から 0.2 の間で設定した。

1) ロールスクリーン

Fig.4 にロールスクリーン有無での日射熱取得率の関係を示す。 左下方のグラフ群が外付ロールスクリーン, 右上方のグラフ群が内 付ロールスクリーンであり, それぞれのグラフ群の横方向は, ロー ルスクリーンの日射反射率違い（0.0 から 1.0 まで 0.2 間隔）, 縦方 向は，日射透過率違い（0.0 から 1.0 まで 0.2 間隔）を示している。 図の個々のグラフ中の標本数は, 28 ガラス $\times 19$ 入射角の合計 532 である。図よりいずれのグラフにおいてもロールスクリーンを有す る空の日射熱取得率は, ガラス種, 入射角によらず原点を通る二次 曲線に近似できるので, 直達日射, 天空日射, 地表面反射日射の違 いにかかわらず式(3)で表すことができる。また，ロールスクリーン による遮蔽効果係数を, ロールスクリーンを有しない空の日射熱取 得率に対するロールスクリーンを有する空の日射熱取得率の比と定 義すると, 式(4)のように表すことができる。得られた遮蔽効果係数 を用いて式(5)の簡易計算式から日射熱取得を算出する。

$$
\begin{aligned}
\eta_{\text {sh }}= & \mathrm{a} \times \eta_{\text {non-sh }}+\mathrm{b} \times \eta_{\text {non-sh }}^{2} \\
\mathrm{f}_{\text {sh }}= & \frac{\eta_{\text {sh }}}{\eta_{\text {non-sh }}}=\mathrm{a}+\mathrm{b} \times \eta_{\text {non-sh }} \\
\mathrm{G}_{\mathrm{w}}^{\prime \prime}(\mathrm{t})= & \left(\mathrm{I}_{\mathrm{d}}(\mathrm{t}) \times \mathrm{f}_{\theta, \mathrm{d}}(\mathrm{t}) \times \mathrm{f}_{\text {sh, d }}(\mathrm{t})+\mathrm{I}_{\mathrm{s}}(\mathrm{t}) \times \mathrm{f}_{\theta, \mathrm{s}} \times \mathrm{f}_{\mathrm{sh}, \mathrm{s}}\right. \\
& \left.+\mathrm{I}_{\mathrm{g}}(\mathrm{t}) \times \mathrm{f}_{\theta, \mathrm{g}} \times \mathrm{f}_{\text {sh, }}\right) \times \eta_{\text {non-sh }, 0} \times \mathrm{A}_{\mathrm{w}}
\end{aligned}
$$

外付ロールスクリーンの場合，ロールスクリーンの日射反射率よ りも日射透過率の方が外付ロールスクリーンを有する空の日射熱取 得率の変化に対する寄与率が大きい。一方, 内付ロールスクリーン の場合，ロールスクリーンの日射透過率は内付ロールスクリーンを 有する空の日射熱取得率の変化にほとんど寄与せず日射反射率のみ に依存して日射熱取得率が変化していることが分かる。したがって, これらの関係を説明変数に多変量解析を行うと係数 $\mathrm{a}, \mathrm{b}$ はそれぞれ 外付ロールスクリーンの場合には式(6), 式(7)で, 内付ロールスク リーンの場合には式(8), 式(9)で整理することができる。Table4に

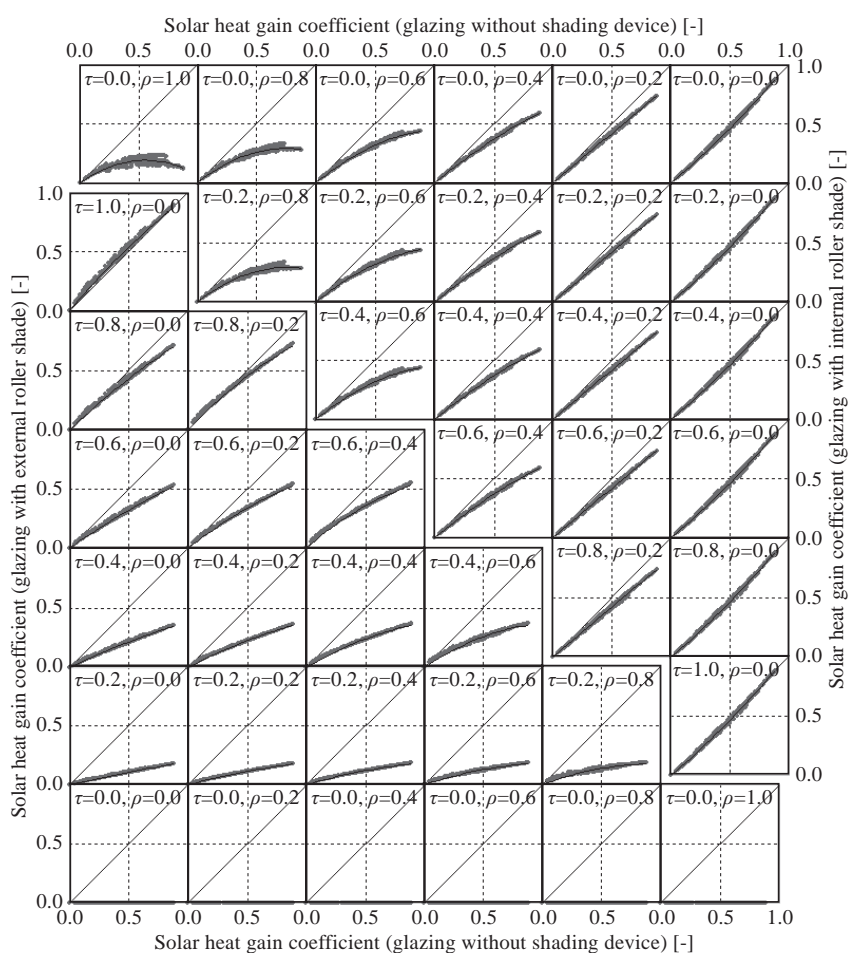

\begin{tabular}{|c|c|c|c|c|c|c|c|}
\hline $\begin{array}{l}\text { Shading } \\
\text { type }\end{array}$ & $\begin{array}{c}\text { Solar } \\
\text { radiation } \\
\text { type }\end{array}$ & $\alpha_{0}$ & $\alpha_{1}$ & $\alpha_{2}$ & $\beta_{0}$ & $\beta_{1}$ & $\beta_{2}$ \\
\hline \multirow{3}{*}{$\begin{array}{l}\text { External } \\
\text { roller } \\
\text { shade }\end{array}$} & Direct & 1.186 & 0.541 & 0.413 & -0.225 & -0.538 & -0.533 \\
\hline & $\begin{array}{c}\text { Sky } \\
\text {-diffuse }\end{array}$ & 1.187 & 0.498 & 0.326 & -0.236 & -0.483 & -0.404 \\
\hline & $\begin{array}{l}\text { Ground } \\
\text {-diffuse }\end{array}$ & 1.187 & 0.498 & 0.326 & -0.236 & -0.483 & -0.404 \\
\hline \multirow{3}{*}{$\begin{array}{l}\text { Internal } \\
\text { roller } \\
\text { shade }\end{array}$} & Direct & 0.833 & 0.108 & -0.232 & 0.181 & -1.001 & 0.174 \\
\hline & $\begin{array}{c}\text { Sky } \\
\text {-diffuse }\end{array}$ & 0.833 & 0.096 & -0.205 & 0.187 & -1.020 & 0.135 \\
\hline & $\begin{array}{c}\text { Ground } \\
\text {-diffuse }\end{array}$ & 0.833 & 0.096 & -0.205 & 0.187 & -1.020 & 0.135 \\
\hline
\end{tabular}

Fig.4 Comparison of solar heat gain coefficient (glazing with roller shade vs. without shading device)

Table4 Regression coefficients in the case of roller shade (hourly)

ロールスクリーンでの近似式の回帰係数を示す。

外付ロールスクリーンの場合,

$$
\begin{aligned}
& \mathrm{a}=\left(\alpha_{0}+\alpha_{1} \times \rho+\alpha_{2} \times \rho^{2}\right) \times \tau \\
& \mathrm{b}=\left(\beta_{0}+\beta_{1} \times \rho+\beta_{2} \times \rho^{2}\right) \times \tau
\end{aligned}
$$

内付ロールスクリーンの場合,

$$
\begin{aligned}
& \mathrm{a}=\alpha_{0}+\alpha_{1} \times \rho+\alpha_{2} \times \rho^{2} \\
& \mathrm{~b}=\beta_{0}+\beta_{1} \times \rho+\beta_{2} \times \rho^{2}
\end{aligned}
$$

2) ベネシャンブラインド

Fig.5, Fig.6 に外付ブラインド（スラット角 $+45^{\circ}$ ） と内付ブラ インド（スラット角 $+45^{\circ}$ ）有無での日射熱取得率の関係をそれぞ れ示す。図の横方向は, ブラインドスラット材の日射反射率違い ( 0.0 から 1.0 まで 0.2 間隔), 縦方向は, 日射のプロファイル角違い（一 $\left.75^{\circ},-45^{\circ}, \pm 0^{\circ},+45^{\circ},+75^{\circ}\right)$ を示している。図の個々の 


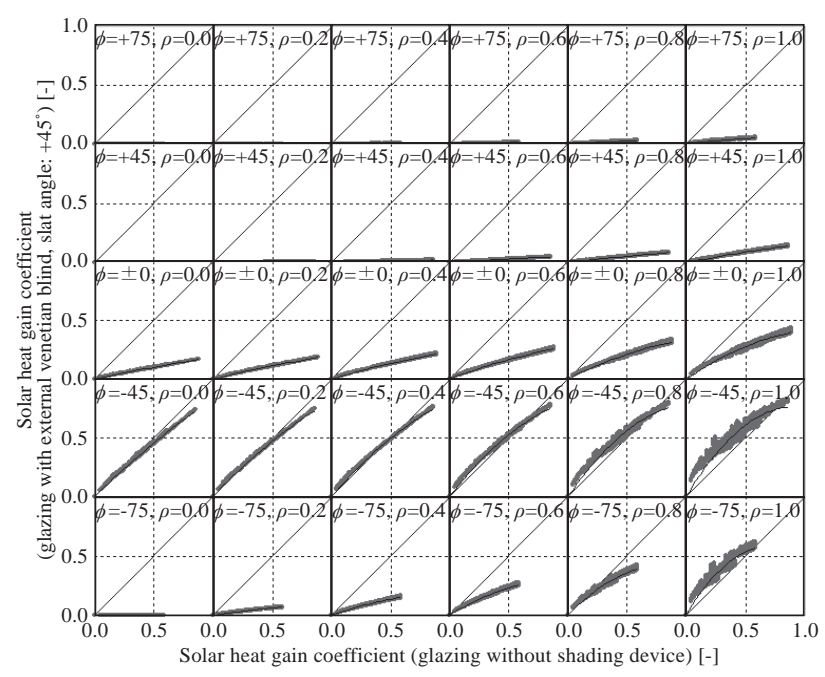

Fig.5 Comparison of solar heat gain coefficient

(glazing with external venetian blind, slat angle: $+45^{\circ}$ vs. without shading device)

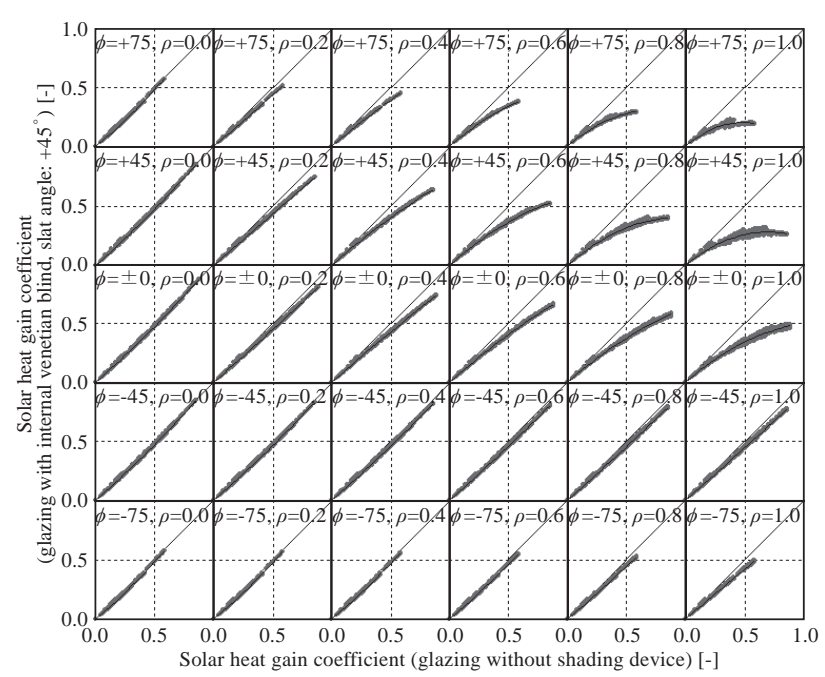

Fig.6 Comparison of solar heat gain coefficient

(glazing with internal venetian blind, slat angle: $+45^{\circ}$ vs. without shading device)

グラフ中の標本数は, 28 ガラス $\times 19$ 方位角 $\times 5$ 鏡面反射率比の合 計 2660 である。図よりいずれのグラフにおいてもブラインドを有 する空の日射熱取得率は, ガラス種, 入射角によらずロールスクリ ーンと同様に原点を通る二次曲線に近似でき式(3)で表すことがで きるので, 式(4)によって得られた遮蔽効果係数を用いて式(5)の簡 易計算式から日射熱取得を算出する。Fig.7, Fig.8 に外付ブライン ドと内付ブラインドのスラット材の日射反射率違いでのプロファイ ル角と係数 a, bの関係をスラット角ごとに示す。Fig.7 (外付ブラ インド）の場合, 係数 a（すなわち, $\eta_{\text {non-sh }}=0.0$ の場合のブラインド の遮蔽効果係数 $\mathrm{f}_{\mathrm{sh}}$ ) は日射反射率が高いほど大きい。これは, ブラ インドがない場合はガラス面で屋外側への反射日射となっていたの に対して, ブラインドを設置した場合は主にブラインド層の直接透 過日射がブラインド層とガラス層との間で多重反射した結果, 室内 側への日射熱取得になったためと考えられる。一方, Fig.8（内付ブ ラインド）の場合, 直接透過日射が支配的な角度（例えば，スラッ 卜角 $-45^{\circ}$ のときのプロファイル角 $+45^{\circ}$ ) ではない場合に係数 b は日射反射率が高いほど小さい。そのため, 日射熱取得率の高いガ ラスと日射反射率の高いブラインドの組合せでブラインドの遮蔽効

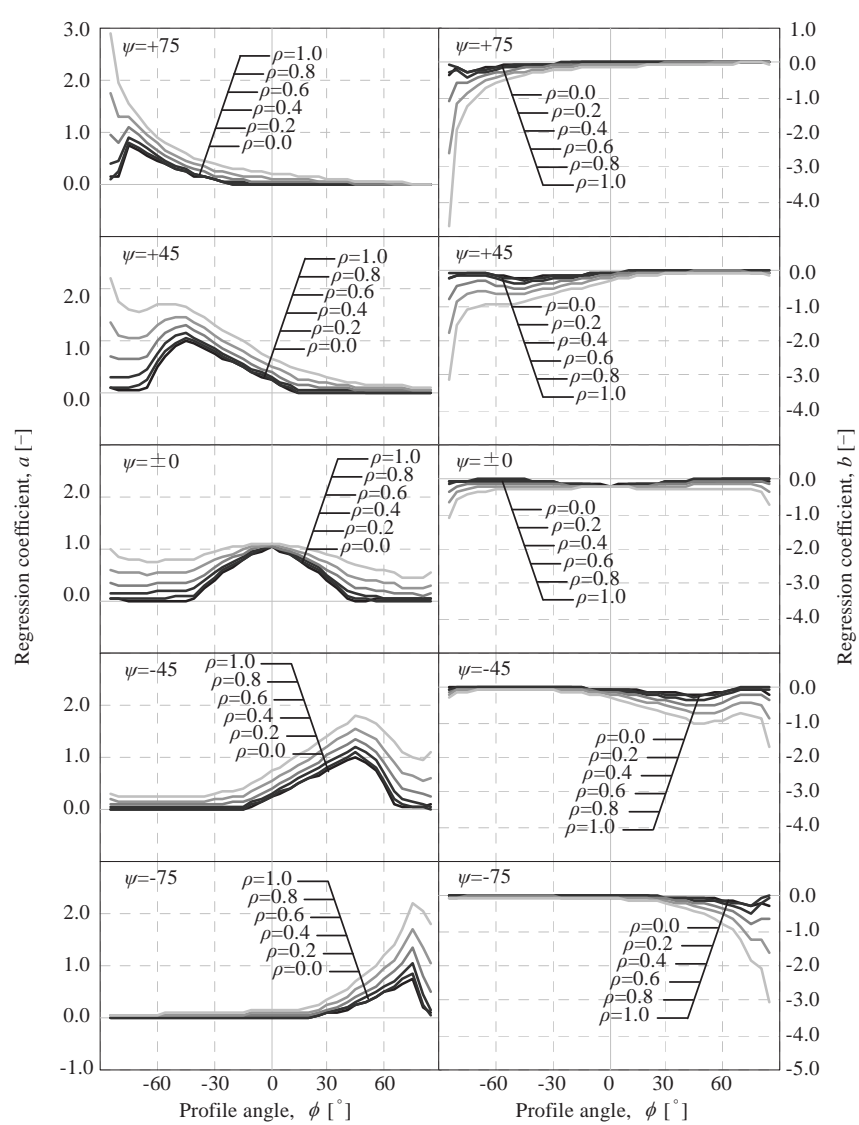

Fig.7 Regression coefficient profile, $a$ and bused in Eq.(4) (hourly, glazing with external venetian blind)

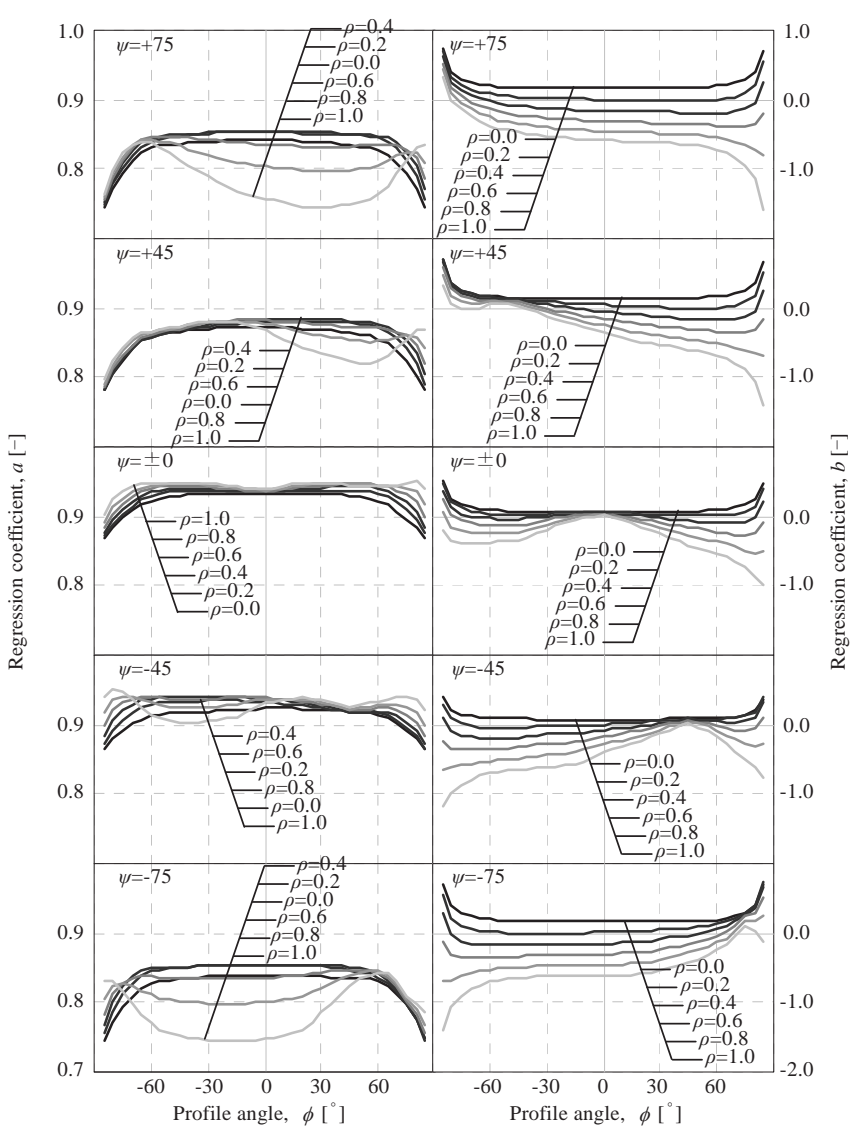

Fig.8 Regression coefficient profile, a and bused in Eq.(4) (hourly, glazing with internal venetian blind) 
Table5 Regression coefficients in the case of venetian blind (hourly)

\begin{tabular}{|c|c|c|c|c|c|c|c|c|c|c|c|c|c|c|c|c|c|c|c|}
\hline $\begin{array}{c}\text { Shading } \\
\text { type }\end{array}$ & $\begin{array}{l}\text { Slat } \\
\text { angle }\end{array}$ & $\begin{array}{c}\text { Solar } \\
\text { radiation } \\
\text { type }\end{array}$ & $\begin{array}{c}\text { Profile } \\
\text { angle }\end{array}$ & $\alpha_{0}$ & $\alpha_{1}$ & $\alpha_{2}$ & $\beta_{0}$ & $\beta_{1}$ & $\beta_{2}$ & $\begin{array}{c}\text { Shading } \\
\text { type }\end{array}$ & $\begin{array}{c}\text { Slat } \\
\text { angle }\end{array}$ & $\begin{array}{c}\text { Solar } \\
\text { radiation } \\
\text { type }\end{array}$ & $\begin{array}{l}\text { Profile } \\
\text { angle }\end{array}$ & $\alpha_{0}$ & $\alpha_{1}$ & $\alpha_{2}$ & $\beta_{0}$ & $\beta_{1}$ & $\beta_{2}$ \\
\hline \multirow{75}{*}{$\begin{array}{c}\text { External } \\
\text { venetian } \\
\text { blind }\end{array}$} & & & $+90^{\circ}$ & 0.000 & 0.000 & 0.000 & 0.000 & 0.000 & 0.000 & & & & $+90^{\circ}$ & 0.000 & 0.000 & 0.000 & 0.000 & 0.000 & 0.000 \\
\hline & & & $+75^{\circ}$ & 0.000 & -0.004 & 0.024 & 0.000 & 0.003 & -0.009 & & & & $+75^{\circ}$ & 0.793 & 0.122 & -0.101 & 0.295 & -0.990 & -0.253 \\
\hline & & & $+60^{\circ}$ & 0.001 & -0.010 & 0.052 & -0.001 & 0.009 & -0.025 & & & & $+60^{\circ}$ & 0.827 & 0.131 & -0.195 & 0.201 & -1.003 & 0.084 \\
\hline & & & $+45^{\circ}$ & 0.002 & -0.024 & 0.096 & -0.002 & 0.024 & -0.055 & & & & $+45^{\circ}$ & 0.834 & 0.122 & -0.208 & 0.182 & -0.968 & 0.138 \\
\hline & & & $+30^{\circ}$ & 0.004 & -0.042 & 0.143 & -0.004 & 0.044 & -0.093 & & & & $+30^{\circ}$ & 0.838 & 0.116 & -0.211 & 0.175 & -0.944 & 0.146 \\
\hline & & & $+15^{\circ}$ & 0.007 & -0.071 & 0.229 & -0.007 & 0.075 & -0.159 & & & & $+15^{\circ}$ & 0.841 & 0.108 & -0.199 & 0.172 & -0.904 & 0.131 \\
\hline & & Direct & $\pm 0^{\circ}$ & 0.009 & -0.092 & 0.297 & -0.009 & 0.098 & -0.208 & & & Direct & $\pm 0^{\circ}$ & 0.841 & 0.102 & -0.186 & 0.171 & -0.871 & 0.117 \\
\hline & $+75^{\circ}$ & & $-15^{\circ}$ & 0.011 & -0.121 & 0.389 & -0.011 & 0.129 & -0.275 & & $+75^{\circ}$ & & $-15^{\circ}$ & 0.841 & 0.095 & -0.167 & 0.171 & -0.828 & 0.094 \\
\hline & & & $-30^{\circ}$ & 0.081 & -0.091 & 0.402 & -0.023 & 0.107 & -0.312 & & & & $-30^{\circ}$ & 0.840 & 0.084 & -0.133 & 0.173 & -0.764 & 0.068 \\
\hline & & & $-45^{\circ}$ & 0.230 & -0.009 & 0.375 & -0.048 & 0.037 & -0.351 & & & & $-45^{\circ}$ & 0.837 & 0.071 & -0.094 & 0.178 & -0.688 & 0.039 \\
\hline & & & $-60^{\circ}$ & 0.464 & 0.105 & 0.355 & -0.097 & -0.060 & -0.442 & & & & $-60^{\circ}$ & 0.830 & 0.054 & -0.047 & 0.198 & -0.569 & 0.003 \\
\hline & & & $-75^{\circ}$ & 0.749 & 0.142 & 0.675 & -0.248 & 0.036 & -1.065 & & & & $-75^{\circ}$ & 0.796 & 0.032 & -0.005 & 0.294 & -0.387 & $\begin{array}{l}-0.038 \\
\end{array}$ \\
\hline & & & $-90^{\circ}$ & 0.000 & 0.000 & 0.000 & 0.000 & 0.000 & 0.000 & & & & $-90^{\circ}$ & 0.000 & 0.000 & 0.000 & 0.000 & 0.000 & 0.000 \\
\hline & & Sky-di & iffuse & 0.004 & -0.040 & 0.149 & -0.004 & 0.040 & -0.093 & & & Sky-di & ffuse & 0.841 & 0.101 & -0.185 & 0.178 & -0.945 & 0.107 \\
\hline & & Ground- & diffuse & 0.133 & -0.041 & 0.351 & -0.019 & 0.061 & -0.264 & & & Ground- & diffuse & 0.842 & 0.065 & -0.127 & 0.177 & -0.758 & 0.071 \\
\hline & & & $+90^{\circ}$ & 0.000 & 0.000 & 0.000 & 0.000 & 0.000 & 0.000 & & & & $+90^{\circ}$ & 0.000 & 0.000 & 0.000 & 0.000 & 0.000 & 0.000 \\
\hline & & & $+75^{\circ}$ & 0.005 & -0.055 & 0.170 & -0.005 & 0.053 & -0.112 & & & & $+75^{\circ}$ & 0.822 & 0.108 & -0.076 & 0.268 & -0.875 & -0.279 \\
\hline & & & $+60^{\circ}$ & 0.004 & -0.032 & 0.173 & -0.002 & 0.023 & -0.062 & & & & $+60^{\circ}$ & 0.855 & 0.114 & -0.147 & 0.170 & -0.847 & -0.003 \\
\hline & & & $+45^{\circ}$ & 0.004 & -0.018 & 0.205 & -0.001 & 0.008 & -0.044 & & & & $+45^{\circ}$ & 0.864 & 0.101 & -0.143 & 0.149 & -0.765 & 0.019 \\
\hline & & & $+30^{\circ}$ & 0.006 & -0.030 & 0.323 & -0.003 & 0.028 & -0.098 & & & & $+30^{\circ}$ & 0.869 & 0.085 & -0.119 & 0.141 & -0.661 & -0.011 \\
\hline & & & $+15^{\circ}$ & 0.010 & -0.031 & 0.454 & -0.006 & 0.061 & -0.190 & & & & $+15^{\circ}$ & 0.871 & 0.070 & -0.093 & 0.137 & -0.560 & $\begin{array}{l}-0.046 \\
\end{array}$ \\
\hline & & Direct & $\pm 0^{\circ}$ & 0.229 & -0.016 & 0.460 & -0.043 & 0.053 & -0.268 & & & Direct & $\pm 0^{\circ}$ & 0.872 & 0.049 & -0.054 & 0.136 & -0.449 & -0.050 \\
\hline & $+45^{\circ}$ & & $-15^{\circ}$ & 0.488 & -0.018 & 0.533 & -0.092 & 0.063 & -0.444 & & $+45^{\circ}$ & & $-15^{\circ}$ & 0.872 & 0.033 & -0.026 & 0.138 & -0.341 & $\begin{array}{l}-0.041 \\
\end{array}$ \\
\hline & & & $-30^{\circ}$ & 0.768 & 0.016 & 0.533 & -0.144 & 0.026 & -0.551 & & & & $-30^{\circ}$ & 0.870 & 0.020 & -0.009 & 0.141 & -0.234 & -0.020 \\
\hline & & & $-45^{\circ}$ & 1.012 & 0.185 & 0.463 & -0.189 & -0.151 & -0.556 & & & & $-45^{\circ}$ & 0.866 & 0.009 & -0.001 & 0.149 & -0.106 & -0.005 \\
\hline & & & $-60^{\circ}$ & 0.492 & 0.314 & 0.887 & -0.116 & 0.099 & -0.947 & & & & $-60^{\circ}$ & 0.858 & 0.003 & 0.005 & 0.167 & -0.031 & -0.089 \\
\hline & & & $-75^{\circ}$ & 0.050 & 0.069 & 1.492 & -0.062 & 0.524 & -1.599 & & & & $-75^{\circ}$ & 0.825 & 0.002 & 0.017 & 0.265 & 0.001 & $\begin{array}{l}-0.268 \\
\end{array}$ \\
\hline & & & $-90^{\circ}$ & 0.000 & 0.000 & 0.000 & 0.000 & 0.000 & 0.000 & & & & $-90^{\circ}$ & 0.000 & 0.000 & 0.000 & 0.000 & 0.000 & 0.000 \\
\hline & & Sky-di & iffuse & 0.036 & -0.023 & 0.324 & -0.010 & 0.031 & -0.126 & & & Sky-di & iffuse & 0.868 & 0.081 & -0.103 & 0.147 & -0.664 & -0.036 \\
\hline & & Ground- & diffuse & 0.591 & 0.082 & 0.512 & -0.118 & 0.012 & $\begin{array}{l}-0.431 \\
\end{array}$ & & & Ground- & diffuse & 0.870 & 0.013 & -0.016 & 0.147 & -0.240 & -0.042 \\
\hline & & & $+90^{\circ}$ & 0.000 & 0.000 & 0.000 & 0.000 & 0.000 & 0.000 & & & & $+90^{\circ}$ & 0.000 & 0.000 & 0.000 & 0.000 & 0.000 & 0.000 \\
\hline & & & $+75^{\circ}$ & 0.025 & -0.225 & 0.659 & -0.024 & 0.251 & -0.523 & & & & $+75^{\circ}$ & 0.896 & 0.068 & -0.015 & 0.169 & -0.474 & -0.429 \\
\hline & & & $+60^{\circ}$ & 0.026 & -0.203 & 0.761 & -0.019 & 0.200 & -0.448 & & & & $+60^{\circ}$ & 0.922 & 0.065 & -0.044 & 0.090 & -0.368 & -0.250 \\
\hline & & & $+45^{\circ}$ & 0.022 & -0.018 & 0.700 & -0.016 & 0.140 & -0.398 & & & & $+45^{\circ}$ & 0.929 & 0.047 & -0.031 & 0.073 & -0.249 & $\begin{array}{l}-0.237 \\
\end{array}$ \\
\hline & & & $+30^{\circ}$ & 0.403 & 0.092 & 0.405 & -0.070 & 0.012 & -0.218 & & & & $+30^{\circ}$ & 0.933 & 0.023 & -0.007 & 0.069 & -0.156 & -0.157 \\
\hline & & & $+15^{\circ}$ & 0.799 & 0.070 & 0.164 & -0.130 & -0.033 & -0.084 & & & & $+15^{\circ}$ & 0.934 & 0.010 & 0.001 & 0.069 & -0.093 & -0.075 \\
\hline & & Direct & $\pm 0^{\circ}$ & 1.039 & 0.032 & 0.041 & -0.169 & -0.023 & -0.021 & Internal & & Direct & $\pm 0^{\circ}$ & 0.934 & 0.004 & 0.001 & 0.071 & -0.040 & -0.022 \\
\hline & $\pm 0^{\circ}$ & & $-15^{\circ}$ & 0.788 & 0.107 & 0.168 & -0.128 & -0.024 & -0.081 & venetian & $\pm 0^{\circ}$ & & $-15^{\circ}$ & 0.934 & 0.006 & 0.003 & 0.069 & -0.050 & -0.077 \\
\hline & & & $-30^{\circ}$ & 0.401 & 0.170 & 0.372 & -0.069 & 0.003 & -0.203 & blind & & & $-30^{\circ}$ & 0.933 & 0.016 & -0.001 & 0.069 & -0.103 & -0.162 \\
\hline & & & $-45^{\circ}$ & 0.018 & 0.182 & 0.591 & -0.013 & 0.088 & -0.357 & & & & $-45^{\circ}$ & 0.930 & 0.033 & -0.015 & 0.073 & -0.168 & -0.248 \\
\hline & & & $-60^{\circ}$ & 0.019 & 0.152 & 0.603 & -0.015 & 0.101 & -0.386 & & & & $-60^{\circ}$ & 0.923 & 0.035 & -0.010 & 0.089 & -0.179 & -0.283 \\
\hline & & & $-75^{\circ}$ & 0.022 & 0.070 & 0.715 & -0.020 & 0.139 & -0.524 & & & & $-75^{\circ}$ & 0.897 & 0.024 & 0.016 & 0.169 & -0.161 & -0.387 \\
\hline & & & $-90^{\circ}$ & 0.000 & 0.000 & 0.000 & 0.000 & 0.000 & 0.000 & & & & $-90^{\circ}$ & 0.000 & 0.000 & 0.000 & 0.000 & 0.000 & 0.000 \\
\hline & & Sky-di & iffuse & 0.480 & 0.022 & 0.369 & -0.105 & 0.029 & -0.179 & & & Sky-di & ffuse & 0.931 & 0.032 & -0.005 & 0.075 & -0.177 & -0.163 \\
\hline & & Ground- & diffuse & 0.477 & 0.134 & 0.328 & -0.104 & 0.015 & -0.164 & & & Ground- & diffuse & 0.931 & 0.018 & 0.003 & 0.075 & -0.104 & -0.164 \\
\hline & & & $+90^{\circ}$ & 0.000 & 0.000 & 0.000 & 0.000 & 0.000 & 0.000 & & & & $+90^{\circ}$ & 0.000 & 0.000 & 0.000 & 0.000 & 0.000 & 0.000 \\
\hline & & & $+75^{\circ}$ & 0.038 & -0.123 & 1.075 & -0.048 & 0.451 & -1.171 & & & & $+75^{\circ}$ & 0.893 & 0.015 & 0.032 & 0.146 & 0.021 & -0.674 \\
\hline & & & $+60^{\circ}$ & 0.476 & 0.242 & 0.789 & -0.110 & 0.048 & -0.861 & & & & $+60^{\circ}$ & 0.914 & 0.008 & 0.011 & 0.096 & -0.028 & -0.232 \\
\hline & & & $+45^{\circ}$ & 1.010 & 0.300 & 0.475 & -0.187 & -0.239 & -0.575 & & & & $+45^{\circ}$ & 0.919 & 0.002 & 0.005 & 0.087 & -0.011 & -0.062 \\
\hline & & & $+30^{\circ}$ & 0.763 & 0.160 & 0.486 & -0.137 & -0.118 & -0.460 & & & & $+30^{\circ}$ & 0.922 & 0.014 & 0.000 & 0.081 & -0.117 & -0.088 \\
\hline & & & $+15^{\circ}$ & 0.484 & 0.057 & 0.505 & -0.087 & -0.014 & -0.382 & & & & $+15^{\circ}$ & 0.923 & 0.030 & -0.016 & 0.077 & -0.228 & -0.124 \\
\hline & & Direct & $\pm 0^{\circ}$ & 0.229 & 0.002 & 0.495 & -0.043 & 0.040 & -0.284 & & & Direct & $\pm 0^{\circ}$ & 0.923 & 0.051 & -0.043 & 0.076 & -0.332 & -0.150 \\
\hline & $-45^{\circ}$ & & $-15^{\circ}$ & 0.008 & -0.026 & 0.413 & -0.005 & 0.054 & -0.180 & & $-45^{\circ}$ & & $-15^{\circ}$ & 0.921 & 0.087 & -0.097 & 0.074 & -0.410 & -0.227 \\
\hline & & & $-30^{\circ}$ & 0.005 & 0.014 & 0.274 & -0.003 & 0.019 & -0.096 & & & & $-30^{\circ}$ & 0.919 & 0.101 & -0.115 & 0.076 & -0.441 & -0.246 \\
\hline & & & $-45^{\circ}$ & 0.004 & 0.037 & 0.199 & -0.001 & 0.000 & -0.049 & & & & $-45^{\circ}$ & 0.917 & 0.105 & -0.119 & 0.084 & -0.628 & -0.103 \\
\hline & & & $-60^{\circ}$ & 0.004 & 0.043 & 0.180 & -0.001 & 0.002 & -0.052 & & & & $-60^{\circ}$ & 0.912 & 0.106 & -0.103 & 0.097 & -0.659 & -0.138 \\
\hline & & & $-75^{\circ}$ & 0.005 & 0.034 & 0.202 & -0.004 & 0.015 & -0.103 & & & & $-75^{\circ}$ & 0.891 & 0.086 & -0.031 & 0.155 & -0.632 & -0.379 \\
\hline & & & $-90^{\circ}$ & 0.000 & 0.000 & 0.000 & 0.000 & 0.000 & 0.000 & & & & $-90^{\circ}$ & 0.000 & 0.000 & 0.000 & 0.000 & 0.000 & 0.000 \\
\hline & & Sky-di & iffuse & 0.589 & 0.135 & 0.479 & -0.115 & -0.063 & -0.386 & & & Sky-di & iffuse & 0.923 & 0.014 & -0.003 & 0.081 & -0.144 & $\begin{array}{l}-0.143 \\
\end{array}$ \\
\hline & & Ground- & diffuse & 0.036 & 0.014 & 0.304 & -0.010 & 0.021 & -0.121 & & & Ground- & diffuse & 0.921 & 0.092 & -0.096 & 0.079 & -0.497 & $\begin{array}{l}-0.199 \\
\end{array}$ \\
\hline & & & $+90^{\circ}$ & 0.000 & 0.000 & 0.000 & 0.000 & 0.000 & 0.000 & & & & $+90^{\circ}$ & 0.000 & 0.000 & 0.000 & 0.000 & 0.000 & 0.000 \\
\hline & & & $+75^{\circ}$ & 0.765 & 0.218 & 1.215 & -0.273 & 0.230 & -1.806 & & & & $+75^{\circ}$ & 0.796 & -0.001 & 0.014 & 0.290 & 0.023 & -0.199 \\
\hline & & & $+60^{\circ}$ & 0.484 & 0.020 & 0.685 & -0.109 & 0.033 & -0.707 & & & & $+60^{\circ}$ & 0.830 & 0.036 & -0.022 & 0.193 & -0.303 & -0.143 \\
\hline & & & $+45^{\circ}$ & 0.234 & -0.060 & 0.542 & -0.052 & 0.082 & -0.466 & & & & $+45^{\circ}$ & 0.836 & 0.066 & -0.077 & 0.174 & -0.471 & -0.121 \\
\hline & & & $+30^{\circ}$ & 0.089 & -0.064 & 0.326 & -0.022 & 0.070 & -0.254 & & & & $+30^{\circ}$ & 0.837 & 0.104 & -0.154 & 0.169 & -0.599 & -0.111 \\
\hline & & & $+15^{\circ}$ & 0.007 & -0.076 & 0.241 & -0.007 & 0.076 & -0.165 & & & & $+15^{\circ}$ & 0.838 & 0.124 & -0.207 & 0.169 & -0.746 & $\begin{array}{l}-0.019 \\
\end{array}$ \\
\hline & & Direct & $\pm 0^{\circ}$ & 0.005 & -0.058 & 0.194 & -0.005 & 0.059 & -0.131 & & & Direct & $\pm 0^{\circ}$ & 0.839 & 0.123 & -0.214 & 0.170 & -0.814 & 0.039 \\
\hline & $-75^{\circ}$ & & $-15^{\circ}$ & 0.004 & -0.045 & 0.162 & -0.004 & 0.047 & -0.107 & & $-75^{\circ}$ & & $-15^{\circ}$ & 0.839 & 0.124 & -0.218 & 0.171 & -0.842 & 0.060 \\
\hline & & & $-30^{\circ}$ & 0.003 & -0.032 & 0.131 & -0.003 & 0.035 & -0.084 & & & & $-30^{\circ}$ & 0.837 & 0.125 & -0.216 & 0.174 & -0.871 & 0.075 \\
\hline & & & $-45^{\circ}$ & 0.003 & -0.021 & 0.107 & -0.002 & 0.026 & -0.066 & & & & $-45^{\circ}$ & 0.834 & 0.127 & -0.208 & 0.180 & -0.897 & 0.072 \\
\hline & & & $-60^{\circ}$ & 0.002 & -0.009 & 0.082 & -0.001 & 0.015 & -0.046 & & & & $-60^{\circ}$ & 0.826 & 0.130 & -0.187 & 0.200 & -0.919 & 0.016 \\
\hline & & & $-75^{\circ}$ & 0.001 & 0.005 & 0.065 & -0.001 & 0.006 & -0.036 & & & & $-75^{\circ}$ & 0.793 & 0.113 & -0.089 & 0.292 & -0.885 & -0.312 \\
\hline & & & $-90^{\circ}$ & 0.000 & 0.000 & 0.000 & 0.000 & 0.000 & 0.000 & & & & $-90^{\circ}$ & 0.000 & 0.000 & 0.000 & 0.000 & 0.000 & 0.000 \\
\hline & & Sky-di & iffuse & 0.134 & -0.038 & 0.354 & -0.018 & 0.055 & -0.259 & & & Sky-di & fffuse & 0.840 & 0.075 & -0.144 & 0.174 & -0.597 & -0.073 \\
\hline & & Ground- & diffuse & 0.003 & -0.027 & 0.123 & -0.003 & 0.029 & -0.073 & & & Ground- & diffuse & 0.839 & 0.112 & -0.197 & 0.177 & -0.876 & 0.038 \\
\hline
\end{tabular}


Table6 Calculation condition

Boundary condition: Summer

Climatic data: EA weather data $1981-2000$

Year (365 days): Standard year

City (4 locations): Sapporo, Tokyo, Kagoshima, Naha

Orientation (8 directions): S, SW, W, NW, N, NE, E, SE

Ground reflectance: 0.1

Shading type : R efer to Table2

Glazing type (28 types): Refer to Table3

Table7 Regression coefficients (daily)

\begin{tabular}{|c|c|c|c|c|c|c|c|}
\hline $\begin{array}{c}\text { Shading } \\
\text { type }\end{array}$ & $\begin{array}{c}\text { Slat } \\
\text { angle }\end{array}$ & $\alpha_{0}$ & $\alpha_{1}$ & $\alpha_{2}$ & $\beta_{0}$ & $\beta_{1}$ & $\beta_{2}$ \\
\hline \multicolumn{2}{|c|}{ External roller shade } & 1.187 & 0.498 & 0.333 & -0.236 & -0.484 & -0.413 \\
\hline \multicolumn{2}{|c|}{ Internal roller shade } & 0.833 & 0.090 & -0.202 & 0.187 & -1.012 & 0.132 \\
\hline \multirow{5}{*}{$\begin{array}{c}\text { External } \\
\text { venetian } \\
\text { blind }\end{array}$} & $+75^{\circ}$ & 0.020 & -0.037 & 0.164 & -0.009 & 0.039 & -0.107 \\
\hline & $+45^{\circ}$ & 0.103 & -0.010 & 0.330 & -0.039 & 0.024 & -0.144 \\
\hline & $\pm 0^{\circ}$ & 0.432 & 0.026 & 0.393 & -0.083 & 0.042 & -0.199 \\
\hline & $-45^{\circ}$ & 0.520 & 0.130 & 0.470 & -0.063 & -0.060 & -0.380 \\
\hline & $-75^{\circ}$ & 0.141 & -0.032 & 0.349 & -0.036 & 0.047 & -0.263 \\
\hline \multirow{5}{*}{$\begin{array}{c}\text { Internal } \\
\text { venetian } \\
\text { blind }\end{array}$} & $+75^{\circ}$ & 0.841 & 0.094 & -0.178 & 0.178 & -0.923 & 0.100 \\
\hline & $+45^{\circ}$ & 0.869 & 0.074 & -0.095 & 0.147 & -0.628 & -0.037 \\
\hline & $\pm 0^{\circ}$ & 0.931 & 0.030 & -0.008 & 0.075 & -0.175 & -0.166 \\
\hline & $-45^{\circ}$ & 0.922 & 0.018 & -0.018 & 0.081 & -0.167 & -0.138 \\
\hline & $-75^{\circ}$ & 0.840 & 0.073 & -0.140 & 0.174 & -0.607 & -0.076 \\
\hline
\end{tabular}

果係数 $\mathrm{f}_{\mathrm{sh}}$ をより小さくできることが分かる。ブラインドスラットの 日射反射率を説明変数に多変量解析を行うと係数 $a, b$ は式 (8), 式 (9)で整理することができる。Table5 にブラインドでの近似式の代 表的な回帰係数を示す。

\section{4. 日積算の日射熱取得の簡易計算法}

ブラインドは，プロファイル角特性を有するため期間積算の日射 熱取得を計算する際，時刻ごとにその時刻のプロファイル角に対応 する回帰係数を Table5 から選択する必要があり少々複雑である。 ここでは，日積算の日射熱取得に基づいて期間積算の日射熱取得の 簡易計算法を検討する。空面受照日積算日射量, 詳細計算による空 の日積算日射熱取得及び日平均日射熱取得率は，日射遮蔽物の有無 にかかわらず式(10)，式(11)及び式(12)によって得られる。

$$
\begin{aligned}
& J_{\text {day }}=\int_{\text {day }}\left[I_{d}(t)+I_{s}(t)+I_{g}(t)\right] d t \\
& G_{w, d a y}=\int_{\text {day }}\left[\left(I_{d}(t) \times \eta_{d}(t)+I_{s}(t) \times \eta_{s}+I_{g}(t) \times \eta_{g}\right)\right] d t \times A_{w} \\
& \eta_{\text {day }}=\frac{G_{w, d a y}}{J_{\text {day }} \times A_{w}}
\end{aligned}
$$

Fig.9，Fig.10 に Table6 に示す計算条件で得られた日射遮蔽物有 無での日平均日射熱取得率の関係を示す。罒の横方向は，ブライン ドスラット材の日射反射率違い（0.0 から 1.0 まで 0.2 間隔）, 縦方 向は, ブラインドのスラット角違い $\left(-75^{\circ},-45^{\circ}, \pm 0^{\circ},+45^{\circ}\right.$, $\left.+75^{\circ}\right)$ を示している。図の個々のグラフ中の標本数は, 28 ガラス $\times 4$ 地点 $\times 8$ 方位 $\times 365$ 日 $\times 5$ 鏡面反射率比の合計 1635200 である。 図より外付ブラインドの場合は，スラット角 $+75^{\circ}$ を除いてプロッ トのバラつきが大きい。これは，ブラインド層での直接透過日射が プロファイル角によって大きく異なり，かつ吸収日射が室内側へ流 入しないためと考えられる。内付ブラインドの場合は, 日射反射率 1.0 でプロットのバラつきが多少大きい。日射遮蔽物を有する空の 日平均日射熱取得率を時刻別の場合と同様に原点を通る二次曲線に 近似すると式(13)で表すことができる。また，日射遮蔽物による日 平均の遮蔽効果係数を, 日射遮蔽物を有しない空の日平均日射熱取

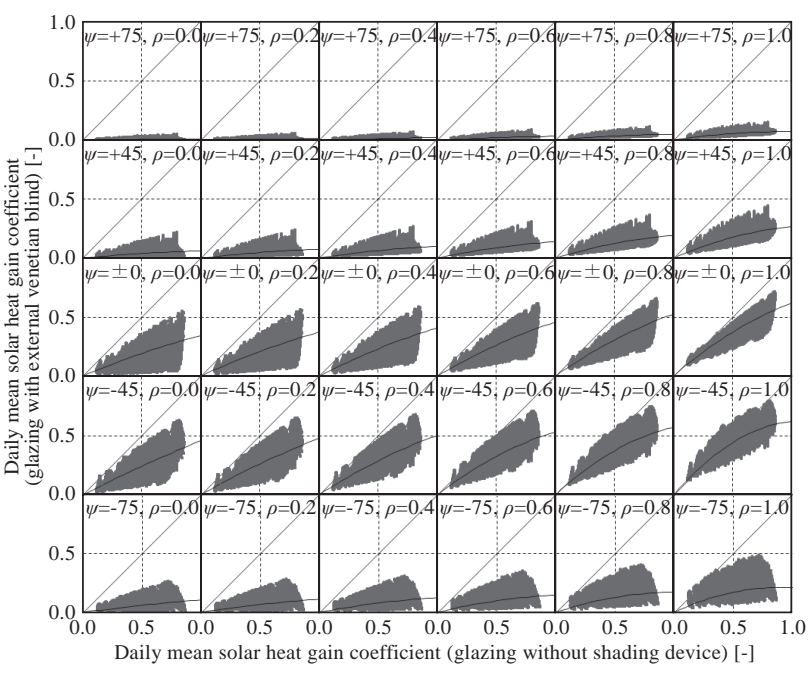

Fig.9 Comparison of daily mean solar heat gain coefficient (glazing with external venetian blind vs. without shading device)

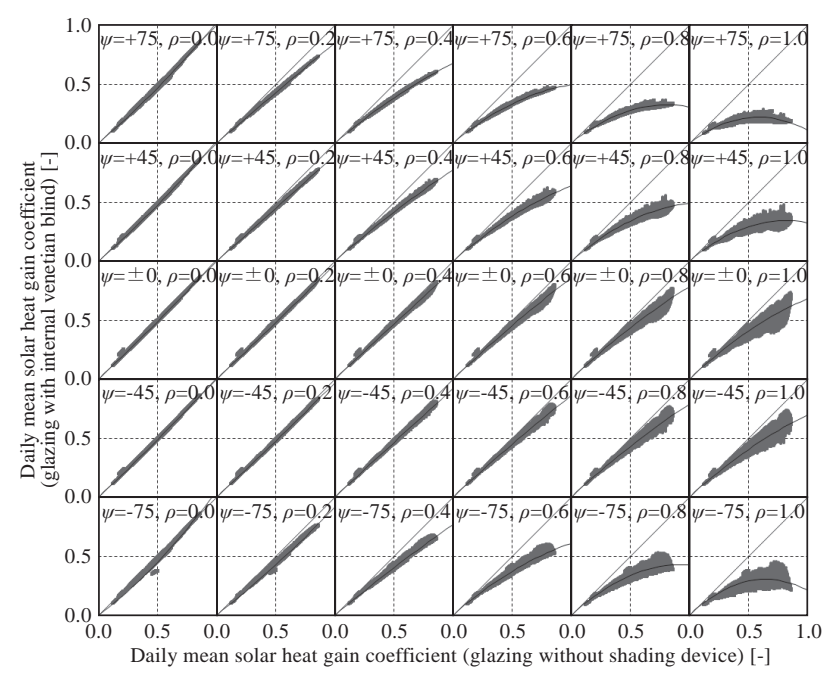

Fig.10 Comparison of daily mean solar heat gain coefficient (glazing with internal venetian blind vs. without shading device)

得率に対する日射遮蔽物を有する空の日平均日射熱取得率の比と定 義すると，式(14)のように表すことができる。得られた遮蔽効果係 数を用いて式(15)の簡易計算式注 ${ }^{4)}$ から日積算の日射熱取得を算出 する。

$$
\begin{aligned}
& \eta_{\text {sh,day }}=\mathrm{a} \times \eta_{\text {non-sh,day }}+\mathrm{b} \times \eta_{\text {non-sh,day }}^{2} \\
& \mathrm{f}_{\text {sh,day }}=\frac{\eta_{\text {sh,day }}}{\eta_{\text {non-sh,day }}}=\mathrm{a}+\mathrm{b} \times \eta_{\text {non-sh,day }} \\
& \mathrm{G}_{\mathrm{w}, \text { day }}^{\prime \prime}=\mathrm{J}_{\text {day }} \times \eta_{\text {non-sh, } 0} \times \mathrm{f}_{\theta, \text { day }} \times \mathrm{f}_{\text {sh,day }} \times \mathrm{A}_{\mathrm{w}}
\end{aligned}
$$

時刻別の場合と同様に日射透過率や日射反射率を説明変数に多変 量解析を行うと係数 a, b は外付ロールスクリーンの場合は式 (6), 式(7)で, 内付ロールスクリーン, 外付ブラインド, 内付ブラインド の場合は式(8), 式(9)で整理することができる。Table7に近似式の 回帰係数を示す。

\section{5. 提案モデルの計算精度}

詳細計算での窓の日射熱取得と提案した簡易計算での空の日射熱 
取得の比較を行い提案モデルの計算精度を検証する。

1）時刻別モデル

Fig.11, Fig.12, Fig.13 にロールスクリーン, 外付ブラインド, 内付ブラインドの式 (1)の詳細計算での空の日射熱取得と式 (5)の簡 易計算での窓の日射熱取得の関係を示す。計算の対象地点として東 京を選択した。図の個々のグラフ中の標本数は, ロールスクリーン の場合には 28 ガラス $\times 8$ 方位 $\times 4386$ 時間（昼間）の合計 982464 であり，外付ブラインドまたは内付ブラインドの場合には 28 ガラ ス $\times 8$ 方位 $\times 4386$ 時間（昼間） $\times 5$ 鏡面反射率比の合計 4912320 である。図より, 全てのモデルで MBE 注 ${ }^{5)}= \pm 1.0 \mathrm{Wh} / \mathrm{m}^{2}$ 以下, RMSE 注 5$)=7.0 \mathrm{Wh} / \mathrm{m}^{2}$ 以下となり良好な結果が得られた。特に外付ブライ ンドは，Fig.1 と比較して計算精度が大幅に向上した。

Glazing with internal roller shade

Hourly solar heat gain, $\mathrm{G}_{w} / \mathrm{A}_{\mathrm{w}}$ (detailed calculation) $\left[\mathrm{kW} \mathrm{h} / \mathrm{m}^{2}\right]$

\begin{tabular}{lllllllllllll}
0.0 & 0.5 & 0.0 & 0.5 & 0.0 & 0.5 & 0.0 & 0.5 & 0.0 & 0.5 & 0.0 & 0.5 & 1.0 \\
\hline & 0.0 & 0.0 & 0.0
\end{tabular}

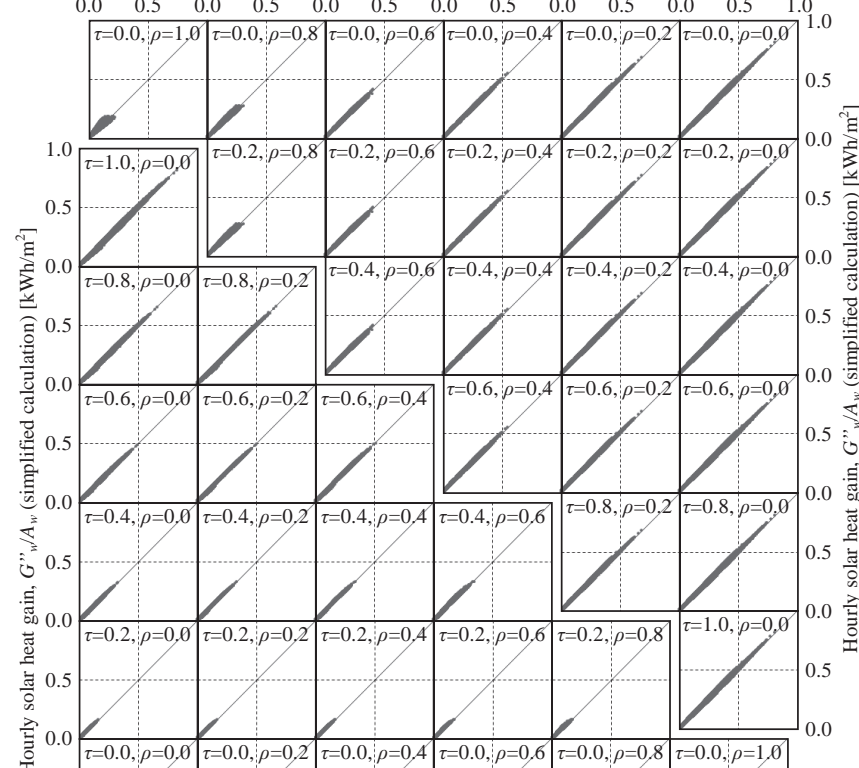

定 $0.0 \tau_{\tau=0.0, \rho=0,0}{ }_{\tau=0.0, \rho=0,2}{ }_{\tau=0.0, \rho=0,4}{ }_{\tau=0.0, \rho=0,6}{ }_{\tau=0.0, \rho=0,8}{ }_{\tau=0.0, \rho=1,0}$

0.5

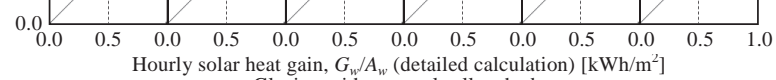

Glazing with external roller shade

\begin{tabular}{|c|c|c|c|c|c|c|c|}
\hline & \multicolumn{7}{|c|}{ MBE $\left[\mathrm{W} / \mathrm{m}^{2}\right]$ G lazing with internal roller shade } \\
\hline & $\rho=1.0$ & $\rho=0.8$ & $\rho=0.6$ & $\rho=0.4$ & $\rho=0.2$ & $\rho=0.0$ & \\
\hline & 0.2 & -0.1 & -0.1 & 0.0 & 0.1 & -0.1 & $\tau=0.0$ \\
\hline$\tau=1.0$ & -0.2 & 0.0 & 0.0 & 0.0 & 0.1 & 0.0 & $\tau=0.2$ \\
\hline$\tau=0.8$ & -0.1 & -0.2 & 0.0 & 0.0 & 0.1 & 0.0 & $\tau=0.4$ \\
\hline$\tau=0.6$ & -0.1 & -0.1 & -0.1 & 0.1 & 0.1 & 0.0 & $\tau=0.6$ \\
\hline$\tau=0.4$ & 0.0 & -0.1 & -0.1 & -0.1 & 0.1 & 0.0 & $\tau=0.8$ \\
\hline$\tau=0.2$ & 0.0 & 0.0 & 0.0 & 0.0 & -0.1 & 0.0 & $\tau=1.0$ \\
\hline \multirow[t]{2}{*}{$\tau=0.0$} & 0.0 & 0.0 & 0.0 & 0.0 & 0.0 & 0.0 & \\
\hline & $\rho=0.0$ & $\rho=0.2$ & $\rho=0.4$ & $\rho=0.6$ & $\rho=0.8$ & $\rho=1.0$ & \\
\hline
\end{tabular}

\begin{tabular}{|c|c|c|c|c|c|c|c|}
\hline & \multicolumn{7}{|c|}{ RMSE [W h/m²] Glazing with internal roller shade } \\
\hline & $\rho=1.0$ & $\rho=0.8$ & $\rho=0.6$ & $\rho=0.4$ & $\rho=0.2$ & $\rho=0.0$ & \\
\hline & 4.7 & 3.1 & 2.0 & 1.6 & 1.8 & 2.3 & $\tau=0.0$ \\
\hline$\tau=1.0$ & 3.4 & 3.1 & 2.0 & 1.6 & 1.8 & 2.3 & $\tau=0.2$ \\
\hline$\tau=0.8$ & 2.7 & 2.1 & 2.1 & 1.6 & 1.8 & 2.3 & $\tau=0.4$ \\
\hline$\tau=0.6$ & 2.0 & 1.6 & 1.8 & 1.7 & 1.8 & 2.3 & $\tau=0.6$ \\
\hline$\tau=0.4$ & 1.4 & 1.0 & 1.2 & 1.9 & 1.8 & 2.3 & $\tau=0.8$ \\
\hline$\tau=0.2$ & 0.7 & 0.5 & 0.6 & 1.0 & 1.6 & 2.3 & $\tau=1.0$ \\
\hline \multirow[t]{2}{*}{$\tau=0.0$} & 0.0 & 0.0 & 0.0 & 0.0 & 0.0 & 0.0 & \\
\hline & $\rho=0.0$ & $\rho=0.2$ & $\rho=0.4$ & $\rho=0.6$ & $\rho=0.8$ & $\rho=1.0$ & \\
\hline
\end{tabular}

Fig.11 Comparison of hourly solar heat gain, MBE and RMSE (roller shade, simplified calculation by Eq.(5) vs. detailed calculation by Eq.(1))

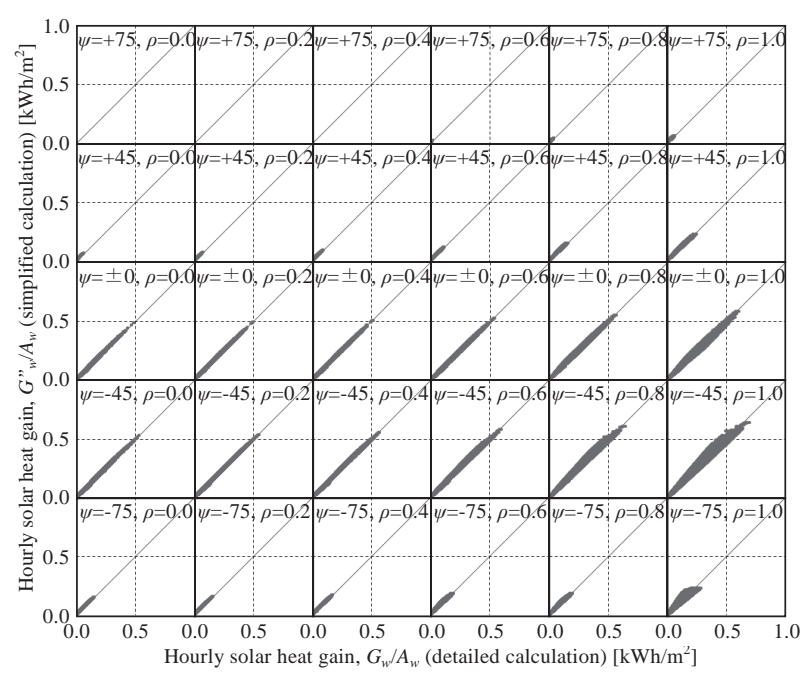

\begin{tabular}{c|c|c|c|c|c|c}
\hline \multicolumn{7}{c|}{$\mathrm{MBE}\left[\mathrm{Wh} / \mathrm{m}^{2}\right]$} \\
\hline & $\rho=0.0$ & $\rho=0.2$ & $\rho=0.4$ & $\rho=0.6$ & $\rho=0.8$ & $\rho=1.0$ \\
\hline$\psi=+75^{\circ}$ & 0.2 & -0.1 & -0.1 & 0.0 & 0.1 & -0.2 \\
\hline$\psi=+45^{\circ}$ & 0.3 & -0.2 & -0.2 & 0.1 & 0.2 & -0.5 \\
\hline$\psi= \pm 0^{\circ}$ & 0.6 & -0.3 & -0.3 & 0.1 & 0.4 & -0.9 \\
\hline$\psi=-45^{\circ}$ & 0.3 & -0.3 & -0.2 & 0.1 & 0.3 & -0.5 \\
\hline$\psi=-75^{\circ}$ & 0.3 & -0.2 & -0.2 & 0.1 & 0.2 & -0.5 \\
\hline \hline \multicolumn{7}{c}{ RMSE $\left[\mathrm{Wh} / \mathrm{m}^{2}\right]$}
\end{tabular}

\begin{tabular}{c|r|r|r|r|r|r}
\hline & $\rho=0.0$ & $\rho=0.2$ & $\rho=0.4$ & $\rho=0.6$ & $\rho=0.8$ & $\rho=1.0$ \\
\hline$\psi=+75^{\circ}$ & 0.2 & 0.1 & 0.1 & 0.2 & 0.4 & 0.8 \\
\hline$\psi=+45^{\circ}$ & 0.5 & 0.3 & 0.3 & 0.5 & 0.9 & 1.4 \\
\hline$\psi= \pm 0^{\circ}$ & 1.2 & 1.0 & 1.2 & 1.5 & 2.3 & 3.6 \\
\hline$\psi=-45^{\circ}$ & 1.5 & 1.2 & 1.5 & 2.4 & 4.0 & 6.1 \\
\hline$\psi=-75^{\circ}$ & 0.7 & 0.5 & 0.7 & 1.2 & 2.3 & 4.0
\end{tabular}

Fig.12 Comparison of hourly solar heat gain, MBE and RMSE (external venetian blind, simplified calculation by Eq.(5) vs. detailed calculation by Eq.(1))

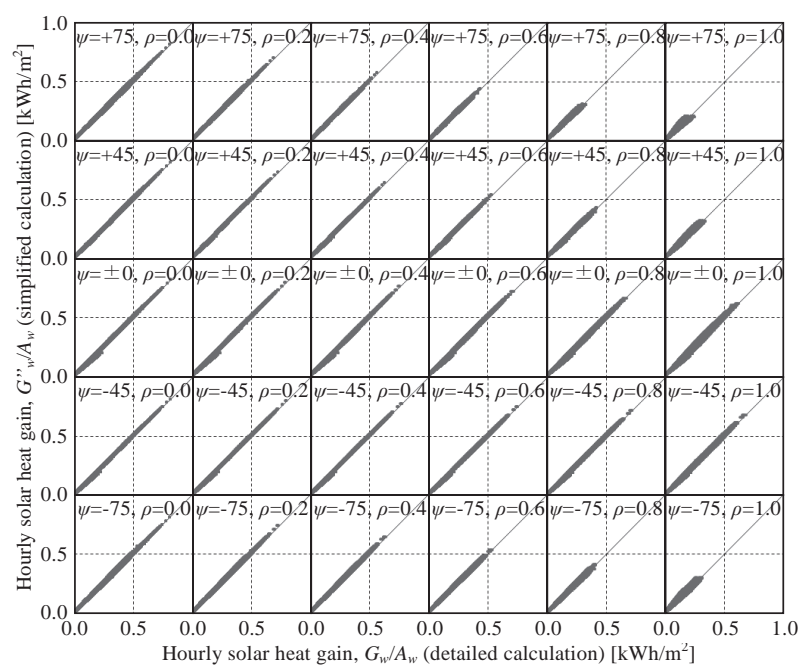

\begin{tabular}{|c|c|c|c|c|c|c|}
\hline \multicolumn{7}{|c|}{$\mathrm{MBE}\left[\mathrm{W} / \mathrm{m}^{2}\right]$} \\
\hline & $\rho=0.0$ & $\rho=0.2$ & $\rho=0.4$ & $\rho=0.6$ & $\rho=0.8$ & $\rho=1.0$ \\
\hline$\psi=+75^{\circ}$ & -0.1 & 0.1 & 0.1 & -0.1 & -0.1 & 0.1 \\
\hline$\psi=+45^{\circ}$ & -0.2 & 0.1 & 0.1 & -0.1 & -0.1 & 0.2 \\
\hline$\psi= \pm 0^{\circ}$ & -0.2 & 0.0 & 0.0 & -0.1 & -0.2 & 0.2 \\
\hline$\psi=-45^{\circ}$ & -0.2 & 0.0 & 0.0 & -0.1 & -0.2 & 0.2 \\
\hline$\psi=-75^{\circ}$ & -0.4 & 0.2 & 0.2 & -0.1 & -0.3 & 0.4 \\
\hline \multicolumn{7}{|c|}{ RMSE $\left[\mathrm{W} \mathrm{h} / \mathrm{m}^{2}\right]$} \\
\hline & $\rho=0.0$ & $\rho=0.2$ & $\rho=0.4$ & $\rho=0.6$ & $\rho=0.8$ & $\rho=1.0$ \\
\hline$\psi=+75^{\circ}$ & 2.1 & 1.6 & 1.5 & 1.9 & 2.8 & 4.2 \\
\hline$\psi=+45^{\circ}$ & 1.7 & 1.4 & 1.4 & 1.7 & 2.4 & 3.5 \\
\hline$\psi= \pm 0^{\circ}$ & 2.1 & 2.0 & 2.1 & 2.2 & 2.6 & 3.2 \\
\hline$\psi=-45^{\circ}$ & 1.6 & 1.5 & 1.5 & 1.6 & 1.8 & 2.1 \\
\hline$\psi=-75^{\circ}$ & 2.1 & 1.8 & 1.7 & 1.8 & 2.4 & 3.5 \\
\hline
\end{tabular}

Fig.13 Comparison of hourly solar heat gain, MBE and RMSE

(internal venetian blind, simplified calculation by Eq.(5) vs. detailed calculation by Eq.(1)) 


\section{2）日積算モデル}

Fig.14, Fig.15, Fig.16にロールスクリーン, 外付ブラインド, 内付ブラインドの式(11)の詳細計算での空の日積算日射熱取得と式 (15)の簡易計算での空の日積算日射熱取得の関係を示す。図の個々 のグラフ中の標本数は, ロールスクリーンは 28 ガラス $\times 4$ 地点 $\times 8$ 方位 $\times 365$ 日の合計 327040 であり, ブラインドは 28 ガラス $\times 4$ 地 点 $\times 8$ 方位 $\times 365$ 日 $\times 5$ 鏡面反射率比の合計 1635200 である。外付 ブラインドは，直接透過日射が多いスラット角で比較結果のバラつ きが大きい。これは，ブラインド層での直接透過日射がプロファイ ル角によって大きく異なり，かつ吸収日射が室内側へ流入しないた めである。しかし，通常使用時は直接透過日射を遮ることが多いの で, スラット角 $+75^{\circ}$ や $+45^{\circ}$ のモデルで簡易に日射熱取得を計算で Glazing with internal roller shade Daily solar heat gain, $G_{w, d a y} / A_{w}$ (detailed calculation) $\left[\mathrm{kW} \mathrm{h} / \mathrm{m}^{2}\right.$


Daily solar heat gain, $G_{w, d a y} / A_{w}$ (detail red calculade
Glazing with external roller shade

\begin{tabular}{|c|c|c|c|c|c|c|c|}
\hline & \multicolumn{7}{|c|}{ MBE $\left[\mathrm{kW} \mathrm{h} / \mathrm{m}^{2}\right]$ Glazing with internal roller shade } \\
\hline & $\rho=1.0$ & $\rho=0.8$ & $\rho=0.6$ & $\rho=0.4$ & $\rho=0.2$ & $\rho=0.0$ & \\
\hline & 0.002 & -0.001 & -0.001 & 0.000 & 0.000 & -0.001 & $\tau=0.0$ \\
\hline$\tau=1.0$ & -0.003 & -0.001 & -0.001 & 0.000 & 0.001 & -0.001 & $\tau=0.2$ \\
\hline$\tau=0.8$ & -0.002 & -0.003 & -0.001 & 0.000 & 0.001 & 0.000 & $\tau=0.4$ \\
\hline$\tau=0.6$ & -0.001 & -0.002 & -0.002 & 0.000 & 0.001 & 0.000 & $\tau=0.6$ \\
\hline$\tau=0.4$ & -0.001 & -0.001 & -0.001 & -0.002 & 0.001 & 0.000 & $\tau=0.8$ \\
\hline$\tau=0.2$ & 0.000 & 0.000 & 0.000 & -0.001 & -0.002 & 0.000 & $\tau=1.0$ \\
\hline$\tau=0.0$ & 0.000 & 0.000 & 0.000 & 0.000 & 0.000 & 0.000 & \\
\hline & $\rho=0.0$ & $\rho=0.2$ & $\rho=0.4$ & $\rho=0.6$ & $\rho=0.8$ & $\rho=1.0$ & \\
\hline
\end{tabular}

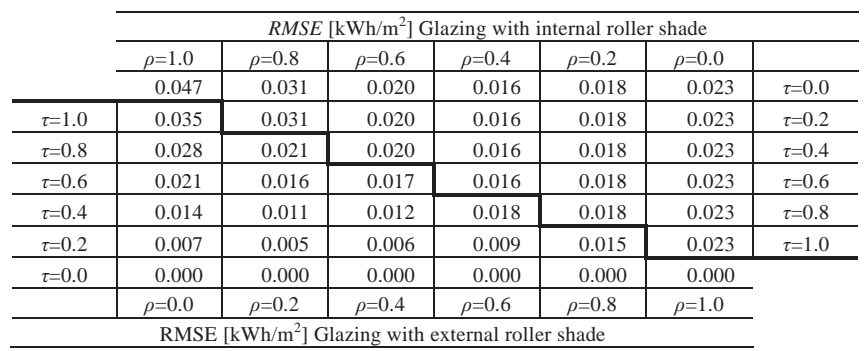

Fig.14 Comparison of daily solar heat gain, MBE and RMSE (roller shade, simplified calculation by Eq.(15) vs. detailed calculation by Eq.(11))

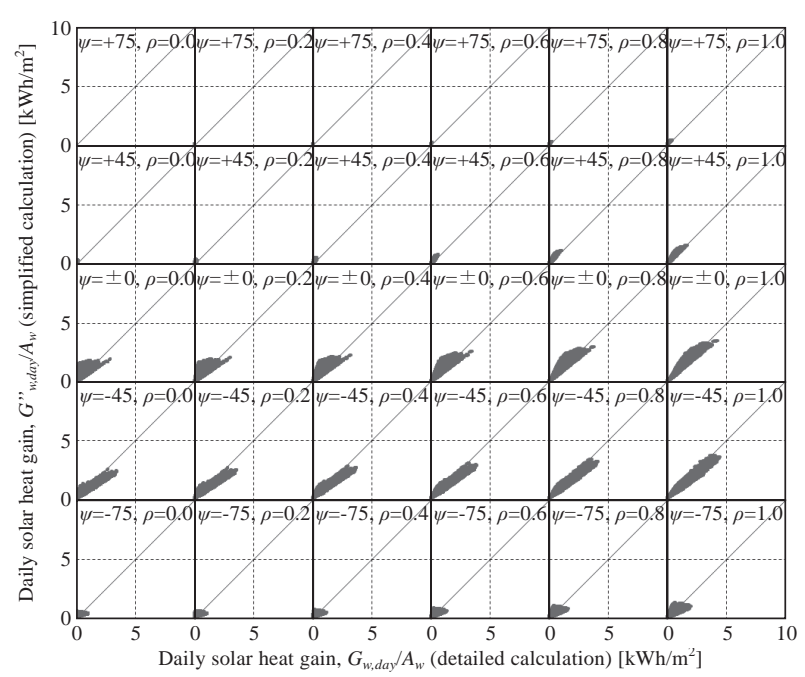

\begin{tabular}{|c|c|c|c|c|c|c|}
\hline \multicolumn{7}{|c|}{ MBE $\left[\mathrm{kW} \mathrm{h} / \mathrm{m}^{2}\right]$} \\
\hline & $\rho=0.0$ & $\rho=0.2$ & $\rho=0.4$ & $\rho=0.6$ & $\rho=0.8$ & $\rho=1.0$ \\
\hline$\psi=+75^{\circ}$ & 0.003 & 0.000 & 0.001 & 0.003 & 0.004 & 0.001 \\
\hline$\psi=+45^{\circ}$ & 0.012 & 0.006 & 0.007 & 0.011 & 0.014 & 0.006 \\
\hline$\psi= \pm 0^{\circ}$ & 0.025 & 0.013 & 0.012 & 0.016 & 0.017 & -0.002 \\
\hline$\psi=-45^{\circ}$ & -0.012 & -0.020 & -0.021 & -0.017 & -0.016 & -0.027 \\
\hline$\psi=-75^{\circ}$ & -0.002 & -0.009 & -0.009 & -0.007 & -0.006 & -0.017 \\
\hline \multicolumn{7}{|c|}{ RMSE $\left[\mathrm{kWh} / \mathrm{m}^{2}\right]$} \\
\hline & $\rho=0.0$ & $\rho=0.2$ & $\rho=0.4$ & $\rho=0.6$ & $\rho=0.8$ & $\rho=1.0$ \\
\hline$\psi=+75^{\circ}$ & 0.007 & 0.006 & 0.007 & 0.009 & 0.013 & 0.016 \\
\hline$\psi=+45^{\circ}$ & 0.034 & 0.032 & 0.033 & 0.038 & 0.044 & 0.045 \\
\hline$\psi= \pm 0^{\circ}$ & 0.106 & 0.097 & 0.092 & 0.088 & 0.079 & 0.061 \\
\hline$\psi=-45^{\circ}$ & 0.102 & 0.104 & 0.103 & 0.099 & 0.097 & 0.105 \\
\hline$\psi=-75^{\circ}$ & 0.047 & 0.052 & 0.056 & 0.061 & 0.070 & 0.087 \\
\hline
\end{tabular}

Fig.15 Comparison of daily solar heat gain, MBE and RMSE (external venetian blind, simplified calculation by Eq.(15) vs. detailed calculation by Eq.(11)

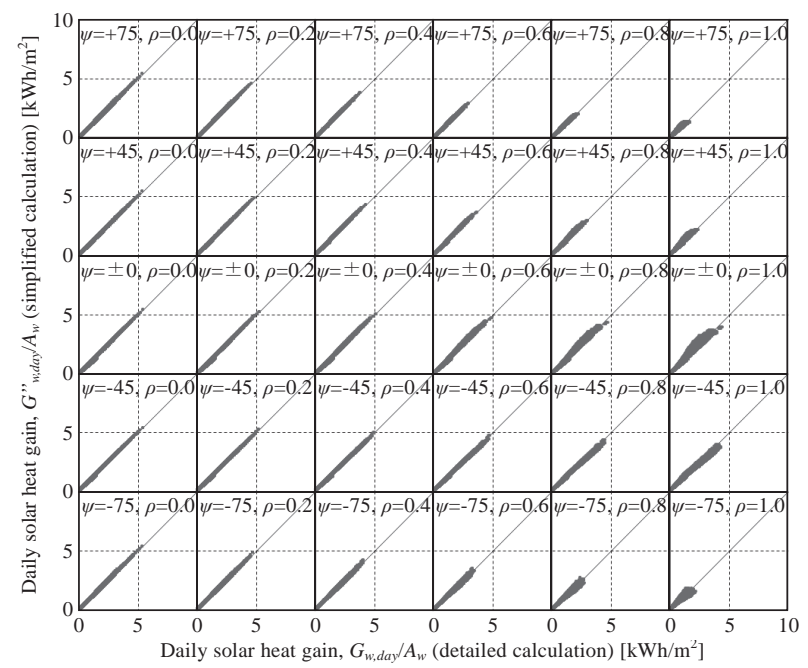

\begin{tabular}{|c|c|c|c|c|c|c|}
\hline \multicolumn{7}{|c|}{ MBE $\left[\mathrm{kWh} / \mathrm{m}^{2}\right]$} \\
\hline & $\rho=0.0$ & $\rho=0.2$ & $\rho=0.4$ & $\rho=0.6$ & $\rho=0.8$ & $\rho=1.0$ \\
\hline$\psi=+75^{\circ}$ & -0.001 & 0.001 & 0.001 & 0.000 & 0.000 & 0.003 \\
\hline$\psi=+45^{\circ}$ & -0.002 & 0.002 & 0.003 & 0.002 & 0.002 & 0.008 \\
\hline$\psi= \pm 0^{\circ}$ & -0.003 & 0.001 & 0.002 & 0.001 & 0.001 & 0.008 \\
\hline$\psi=-45^{\circ}$ & -0.003 & 0.000 & -0.002 & -0.005 & -0.007 & -0.005 \\
\hline$\psi=-75^{\circ}$ & -0.004 & 0.001 & 0.000 & -0.005 & -0.008 & 0.000 \\
\hline \multicolumn{7}{|c|}{ RMSE $\left[\mathrm{kWh} / \mathrm{m}^{2}\right]$} \\
\hline & $\rho=0.0$ & $\rho=0.2$ & $\rho=0.4$ & $\rho=0.6$ & $\rho=0.8$ & $\rho=1.0$ \\
\hline$\psi=+75^{\circ}$ & 0.021 & 0.017 & 0.015 & 0.018 & 0.027 & 0.042 \\
\hline$\psi=+45^{\circ}$ & 0.017 & 0.015 & 0.016 & 0.020 & 0.028 & 0.041 \\
\hline$\psi= \pm 0^{\circ}$ & 0.021 & 0.021 & 0.023 & 0.026 & 0.033 & 0.046 \\
\hline$\psi=-45^{\circ}$ & 0.016 & 0.016 & 0.018 & 0.024 & 0.033 & 0.043 \\
\hline$\psi=-75^{\circ}$ & 0.021 & 0.018 & 0.019 & 0.025 & 0.034 & 0.046 \\
\hline
\end{tabular}

Fig.16 Comparison of daily solar heat gain, MBE and RMSE (internal venetian blind, simplified calculation by Eq.(15) vs. detailed calculation by Eq.(11)) 
きると考えられる。その他のモデルは, $M B E= \pm 0.02 \mathrm{kWh} / \mathrm{m}^{2}$ 以下, RMSE $=0.05 \mathrm{kWh} / \mathrm{m}^{2}$ 以下となり良好な結果が得られた。

\section{6. まとめ}

本研究では, 詳細計算法である JIS A 2103 を用いて計算した日射 遮蔽物を有しない空と日射遮蔽物を有する空の日射熱取得率の関係 から時刻別や日積算での空の日射熱取得の簡易計算法を提案した。 また, 詳細計算と提案した簡易計算による空の日射熱取得の比較を 行い計算の精度を検証した。その結果, 以下の知見が得られた。

（1）日射遮蔽物を有しない空と日射遮蔽物を有寸る空の日射熱取得 率の関係は，原点を通る二次曲線に近似できる。

（2）外付ロールスクリーンの場合, 時刻別・日積算にかかわらずロ ールスクリーンを有しない空の日射熱取得率とロールスクリー ンの日射透過率, 日射反射率を説明変数として様々なガラス種 と外付ロールスクリーンの組合せでの日射熱取得を簡易に計算 できる。

（3）内付ロールスクリーンの場合，時刻別・日積算にかかわらずロ ールスクリーンを有しない空の日射熱取得率とロールスクリー ンの日射反射率を説明変数として様々なガラス種と内付ロール スクリーンの組合せでの日射熱取得を簡易に計算できる。

（4）外付または内付ブラインドの場合, 時刻別・日積算にかかわら ずブラインドを有しない空の日射熱取得率とブラインドスラッ 卜材の日射反射率を説明変数として様々なガラス種とブライン ドの組合せでの日射熱取得を簡易に計算できる。ただし，外付 ブラインドは，直接透過日射が多いスラット角で日積算の日射 熱取得にバラつきが大きいため計算モデルの改良が必要である。

\section{謝辞}

Fig.3 を作成するにあたり, 株式会社ニチベイの佐久間英二氏よ り光学データをご提供いただいた。ここに記して謝意を表する。

\section{記号}

A : 面積 $\left(\mathrm{m}^{2}\right)$

$f:$ 遮蔽効果係数 (-)

G：詳細計算による日射熱取得 (Wh)

$G^{\prime}$ : 斜め入射に対するガラスの遮蔽効果を考慮した簡易計算による日射熱取 得 $(\mathrm{Wh})$

G" : 斜め入射に対するガラスと日射遮蔽物の遮蔽効果を考慮した簡易計算に

よる日射熱取得 $(\mathrm{Wh})$

1: 日射量 $\left(\mathrm{W} / \mathrm{m}^{2}\right)$

i : 入射角 $\left({ }^{\circ}\right)$

J : 期間積算日射量 $\left(\mathrm{Wh} / \mathrm{m}^{2}\right)$

$\mathrm{t}$ : 時間 $(\mathrm{h})$

$\eta$ : 日射熱取得率 (-)

$\tau:$ 日射透過率 $(-)$

$\rho:$ 日射反射率 $(-)$

$\psi$ : スラット角 $\left(^{\circ}\right)$

$\phi:$ プロファイル角 $\left(^{\circ}\right)$

$\gamma$ : 方位角 $\left.{ }^{\circ}{ }^{\circ}\right)$

$a, b:$ 係数 $(-)$

$\alpha, \beta:$ 回帰係数 (-)

\section{添え字}

w : 空

sh：日射遮蔽物あり

$d$ : 直達日射

non-sh：日射遮蔽物なし
0 : 垂直入射

$\theta:$ ガラスの斜め入射

day : 日間
注

注 1）昼間は，日の出から日没までの太陽高度が正の時間帯を表す。 注 2）プロファイル角は，空面に対する太陽高度の法線方向の成分を表す。 ベネシャンブラインドのスラット角 $(\psi)$ とプロファイル角 $(\phi)$ は, Fig.A の 関係にある。
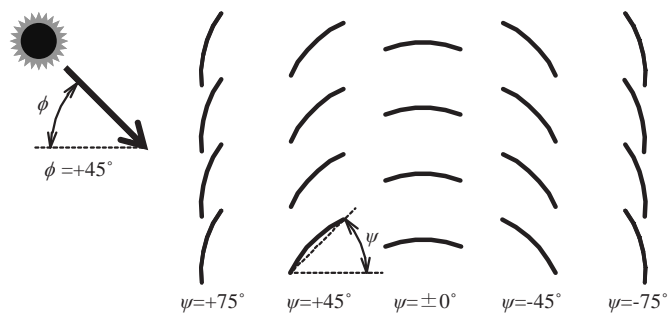

Fig.A Relationship between slat angle and profile angle

注 3) ベネシャンブラインドのスラット材の光学データは, 株式会社ニチ心゙ イから提供されたものである。

注 4) 斜め入射に対するガラスの遮蔽効果係数 $\mathrm{f}_{\theta, \mathrm{d} d \mathrm{y}}$ は, 式(A), 式(B)を用い て日別に得られる。

$$
\begin{aligned}
& f_{\theta, \text { day }}=\frac{\mathrm{G}_{w, \text { non-sh,day }}}{J_{\text {day }} \times \eta_{\text {non-sh, } 0}} \\
& G_{w, \text { non-sh,day }}=\int_{\text {day }}\left[\left(I_{d}(t) \times \eta_{\text {non-sh,d }}(t)+I_{s}(t) \times \eta_{\text {non-sh, s }}+I_{g}(t) \times \eta_{\text {non-sh, }}\right)\right] d t
\end{aligned}
$$

注 5）詳細計算による空の日射熱取得と簡易計算による空の日射熱取得の平 均値のずれを表す指標 MBE（Mean Bias Error）及び詳細計算による空の 日射熱取得と簡易計算による空の日射熱取得の誤差を表す指標 RMSE （Root Mean Square Error）は，式(C)，式(D)を用いて求められる。

$M B E=\frac{\sum_{k=1}^{N}\left(G_{w, \text { simplified, } k}-G_{w, \text { detalled }, k}\right)}{N}$
$R M S E=\sqrt{\frac{\sum_{k=1}^{N}\left(G_{w, \text { simplified, } k}-G_{w, \text { detalled }, k}\right)^{2}}{N}}$

\section{参考文献}

1）経済産業省・国土交通省：エネルギーの使用の合理化に関する建築主等 及び特定建築物の所有者の判断の基準, 平成 25 年経済産業省・国土交通 省告示第 1 号, 2014.4

2）財団法人建築環境・省エネルギー機構: 住宅の省エネルギー基準の解説, 2002.6

3）国土交通省国土技術政策総合研究所・独立行政法人建築研究所 : 平成 25 年省エネルギー基準に準拠した算定・判断の方法及び解説（II 住宅）, 2013.5

4）財団法人建築環境・省エネルギー機構 : 住宅の平成 25 年省エネルギー基 準の解説，2015.11

5）一般財団法人日本規格協会：JIS A 2103，空及びドアの熱性能一日射熱 取得率の計算, 2014.4

6）一般財団法人日本規格協会：JIS A 1493，空及びドアの熱性能一日射熱 取得率の測定, 2014.4

7）財団法人日本規格協会：JIS R 3106, 板ガラス類の透過率・反射率・放 射率・日射熱取得率の試験方法, 1998.3

8）財団法人建築環境・省エネルギー機構：SMASH for Windows Ver.2 住 宅用熱負荷計算プログラム ユーザーマニュアル，2005.1

9）株式会社建築環境ソリューションズ：温熱環境シミュレーションプログ ラム AE-Sim/Heat 操作マニュアル，2005.2

10）松尾陽, 横山浩一, 石野久彌, 川元昭吾 : 空調設備の動的熱負荷計算入 門，社団法人建築設備技術者協会，1980.3

11）郡公子，石野久彌：熱負荷計算のための空性能值に関する研究 第 2 報 一般空の日射遮蔽性能変動の実用的推定法, 日本建築学会環境系論文集, 第 77 巻，第 672 号，pp.89-93，2012.2

12）赤坂裕, 荒井良延, 井川憲男, 石野久彌, 永村悦子, 永村一雄, 郡公子, 曽我和弘, 西岡真稔, 二宮秀與, 松本真一: 拡張アメダス気象デー夕 1981-2000, 日本建築学会, 2005.8 


\section{A SIMPLIFIED METHODOLOGY FOR CALCULATING SOLAR HEAT GAIN THROUGH WINDOWS WITH SHADING DEVICES}

\section{Teruki KOJIMA* and Hideyo NIMIYA**}

* YKK AP Inc., Grad. Stud., Graduate School of Science and Engineering, Kagoshima Univ., M.Eng. ** Prof., Graduate School of Science and Engineering, Kagoshima Univ., Dr.Eng.

In the cooling/heating loads simulation for buildings, it is too difficult to estimate the solar heat gain through the windows with shading devices using the detailed and complicated calculation method (e.g. JIS A 2103) and the off-normal optical characteristic parameters in each time. This paper proposed a simplified methodology for calculating hourly or daily accumulated solar heat gain through the windows with shading devices using relation between solar heat gain coefficients of glazing with and without shading devices. In addition, this paper showed the accuracy of proposed models. As the results of this study, the following conclusions were obtained;

(1) There is relationship of quadratic approximation passing through the origin between solar heat gain coefficients of the glazing with and without shading device.

(2) In the case of external roller shade, the hourly and daily accumulated solar heat gain through windows of various type of combination of glazing and external roller shade can be calculated by the simplified formula that has explanatory variables for the solar heat gain coefficients of windows without roller shade and solar transmittance and reflectance of the roller shade.

(3) In the case of internal roller shade, the hourly and daily accumulated solar heat gain through windows of various type of combination of glazing and internal roller shade can be calculated by the simplified formula that has explanatory variables for the solar heat gain coefficients of windows without roller shade and solar reflectance of the roller shade.

(4) In the case of either external or internal venetian blinds, the hourly and daily accumulated solar heat gain through windows of various type of combination of glazing and venetian blind can be calculated by the simplified formula that has explanatory variables for the solar heat gain coefficients of windows without venetian blind and solar reflectance of the blind slat. However, in the case of the slat angle of external venetian blind that there is a lot of direct transmitted solar radiation through blind layer, the daily accumulated solar heat gain cannot be calculated with high accuracy. Therefore, the model should be improved in the future. 